\title{
Ash iron mobilization through physicochemical processing in volcanic eruption plumes: a numerical modeling approach
}

\author{
G. A. Hoshyaripour, M. Hort, and B. Langmann \\ Institute of Geophysics, Center for Earth System Research and Sustainability (CEN), Universität Hamburg, \\ Hamburg, Germany \\ Correspondence to: G. A. Hoshyaripour (gholamali.hoshyaripour@uni-hamburg.de)
}

Received: 3 November 2014 - Published in Atmos. Chem. Phys. Discuss.: 22 December 2014

Revised: 16 July 2015 - Accepted: 2 August - Published: 21 August 2015

\begin{abstract}
It has been shown that volcanic ash fertilizes the Fe-limited areas of the surface ocean through releasing soluble iron. As ash iron is mostly insoluble upon the eruption, it is hypothesized that heterogeneous in-plume and in-cloud processing of the ash promote the iron solubilization. Direct evidences concerning such processes are, however, lacking. In this study, a 1-D numerical model is developed to simulate the physicochemical interactions of the gas-ash-aerosol in volcanic eruption plumes focusing on the iron mobilization processes at temperatures between 600 and $0{ }^{\circ} \mathrm{C}$. Results show that sulfuric acid and water vapor condense at $\sim 150$ and $\sim 50^{\circ} \mathrm{C}$ on the ash surface, respectively. This liquid phase then efficiently scavenges the surrounding gases (> $95 \%$ of $\mathrm{HCl}, 3-20 \%$ of $\mathrm{SO}_{2}$ and $12-62 \%$ of $\mathrm{HF}$ ) forming an extremely acidic coating at the ash surface. The low $\mathrm{pH}$ conditions of the aqueous film promote acid-mediated dissolution of the Fe-bearing phases present in the ash material. We estimate that $0.1-33 \%$ of the total iron available at the ash surface is dissolved in the aqueous phase before the freezing point is reached. The efficiency of dissolution is controlled by the halogen content of the erupted gas as well as the mineralogy of the iron at ash surface: elevated halogen concentrations and presence of $\mathrm{Fe}^{2+}$-carrying phases lead to the highest dissolution efficiency. Findings of this study are in agreement with the data obtained through leaching experiments.
\end{abstract}

\section{Introduction}

In 2010, sockeye salmon unexpectedly reached record numbers in British Columbia's Fraser River after low numbers during recent decades (Larkin, 2010). It has been hypothesized that the soluble iron contained in the volcanic ash from the eruption of Kasatochi Volcano, Aleutian Islands, in 2008, could have indirectly provided a feast for the salmon (Parsons and Whitney, 2012) through an enhanced marine primary productivity (MPP) and phytoplankton bloom upon ash deposition into Fe-limited ocean surface waters (Olgun et al., 2013a). This phytoplankton bloom was indeed the first direct evidence of a fertilization effect of volcanic ash iron on the surface ocean (Langmann et al., 2010; Hamme et al., 2010). While small-scale ash iron fertilization events (e.g., after the Eyjafjallajökull eruption in 2010, Iceland) trigger perturbations in the local marine biogeochemistry (Olgun et al., 2013b; Achterberg et al., 2013), large-scale events (e.g., the 1991 eruption of Mt. Pinatubo, Philippines) may stimulate the MPP and, in turn, the atmospheric $\mathrm{CO}_{2}$ drawdown globally (Sarmiento, 1993; Watson, 1997) with significant impacts on the climate system (Robock, 2000).

Upon eruption and near the volcanic vent, iron in the ash occurs mostly in non-soluble forms, i.e., in silicate glass and in primary $\mathrm{Fe}$-bearing silicates and $\mathrm{Fe}$-oxide minerals (Heiken and Wohletz, 1992). In the surface ocean, however, the soluble species on the ash surface are suggested to be the main source of iron altering the marine biogeochemistry (Hamme et al., 2010; Duggen et al., 2010; Achterberg et al., 2013; Censi et al., 2010). Solubility of iron in airborne particles (e.g., mineral dust) is known to be strongly linked to its chemical speciation and mineralogy (Schroth et al., 2009; Journet et al., 2008). However, it is not yet fully un- 
Table 1. Different zones of the plume that affect the fine ash during a plinian and subplinian volcanic eruptions.

\begin{tabular}{|c|c|c|c|c|c|}
\hline Zone & Location & Subzones & Timescale $^{\mathrm{a}}$ & Length scale & Temperature \\
\hline Conduit & fragmentation level to vent & - & $6-275 s$ & $\begin{array}{l}\text { few meters to few kilome- } \\
\text { ters }\end{array}$ & $T>600^{\circ} \mathrm{C}$ \\
\hline Plume & vent to NBL & $\begin{array}{l}\text { high-T } \\
\text { mid-T } \\
\text { low-T }\end{array}$ & $150-250 \mathrm{~s}$ & $\begin{array}{l}\text { few kilometers to tens of } \\
\text { kilometers }\end{array}$ & $>$ ambient \\
\hline Cloud & after NBL & $\begin{array}{l}\text { warm } \\
\text { cold }\end{array}$ & hours to days & $>$ hundreds of kilometers & $\sim$ ambient \\
\hline
\end{tabular}

${ }^{\text {a }}$ From Ayris et al. (2013), Hort and Gardner (2000) and Rose and Durant (2009) for conduit, plume and cloud zones, respectively; ${ }^{\mathrm{b}}$ high-T: $T>600{ }^{\circ} \mathrm{C}$, mid-T: $150^{\circ} \mathrm{C}<T<600^{\circ} \mathrm{C}$ and low-T: $50^{\circ} \mathrm{C}<T<150^{\circ} \mathrm{C}$; ${ }^{\mathrm{c}}$ warm zone: $T>$ freezing point $\left(\sim 0^{\circ} \mathrm{C}\right)$, cold zone: $T<$ freezing point.

derstood which volcanic and atmospheric processes control these properties and thereby modulate the ash iron solubility.

Volcanic ash is the tephra with a diameter $<2 \mathrm{~mm}$ (Rose and Durant, 2009), typically composed of silicate glass and crystalline materials generated by fragmentation of the rising magma as well as erosion of the conduit wall rock (Heiken and Wohletz, 1992). While physical properties of the ash (size distribution, specific surface area etc.) are usually dictated by the fragmentation and eruption mechanism, its bulk mineralogy and composition are controlled by cooling and crystallization of the source magma (Dingwell et al., 2012).

During the transport from the magma fragmentation to the high altitudes in the atmosphere and finally to the surface ocean, ash undergoes numerous physicochemical processes within the volcanic conduit, plume and cloud (Table 1). As a result, the surface of the ash does not necessarily mirror the mineralogy and composition of the source magma since it constantly interacts with volcanic gases, aerosols and ambient air (Horwell et al., 2003; Delmelle et al., 2007). For instance, Bagnato et al. (2013) observed a significant difference between the leachate compositions of the proximal and distal ash deposits of the Eyjafjallajökull eruption in 2010, Iceland. These alterations in the ash leachate composition are attributed to the in-plume and in-cloud processing of the volcanic ash surface (Bagnato et al., 2013). Reviews of such processes are provided, for example, by Textor et al. (2005). Here we briefly summarize those processes that are relevant for ash iron mobilization during plinian and subplinian eruptions (for a detailed review please see Ayris and Delmelle, 2012).

In-conduit processes refer to high-temperature postfragmentation subterranean gas-ash interaction. Large explosive eruptions with deep magma fragmentation are likely to be affected by significant in-conduit gas-tephra interaction at temperatures above $600{ }^{\circ} \mathrm{C}$ (Ayris et al., 2013). Such interactions can account for $\mathrm{SO}_{2}$ scavenging by glass-rich tephra that proceeds by a $\mathrm{Ca}^{2+}$ diffusion-driven mechanism (Ayris et al., 2013). It is also suggested that high-temperature $\mathrm{HCl}$ adsorption prior to the mixing of the erupted material with the ambient air could produce minor quantities of $\mathrm{Fe}$ bearing salts on the ash surface (Ayris et al., 2014). Although these findings provide valuable experimental evidences, it is difficult to quantitatively estimate the contribution of such processes in the ash iron mobilization and its relevance to the ocean fertilization. Therefore, the question of whether or not such high-temperature processes can be considered as the dominant mode of ash iron mobilization is difficult to answer.

In-plume processes encompass a wide range of temperature (from magmatic temperatures down to ambient temperature) and distance (from the vent up to the neutral buoyancy level - NBL) during which the volcanic ejecta is mixed with the ambient air. As shown in Table 1, we can identify three temperature-dependent subzones within the in-plume region: high-, mid- and low-temperature (hereafter referred to as high-, mid- and low-T). Hoshyaripour et al. (2014) investigated the high-T in-plume processes $\left(T>600^{\circ} \mathrm{C}\right)$ through modeling the direct gas-ash interactions governed by mixing of the magmatic gas and ash with the ambient air. They reported that such processes do not solubilize the iron directly but significantly control its mineralogy and oxidation state at the ash surface within a $<100 \mathrm{~nm}$ thick rim. They emphasized that further in-plume and in-cloud processes can play the major role in ash iron mobilization.

Mid- and low-T reactions $\left(T<600^{\circ} \mathrm{C}\right)$ within the eruption plume could alter the ash surface composition and thus potentially influence further (photo)chemical reactions during transport of ash in the atmosphere (Ayris and Delmelle, 2012). It is suggested that sulfuric acid condenses first which is then followed by water condensations in the cloud zone (Óskarsson, 1980). This process develops an acidic coating on the ash surface that is expected to dissolve the ash iron efficiently (Delmelle et al., 2007). In-cloud processing of volcanic ash, which is mainly governed by heterogeneous reactions involving liquid water and ice could also mobilize the insoluble iron contained in the ash surface through, for example, dissolution-precipitation and freezing-melting cycles (Duggen et al., 2010). Ayris and Delmelle (2012) speculated that these processes could eventually lead to formation 


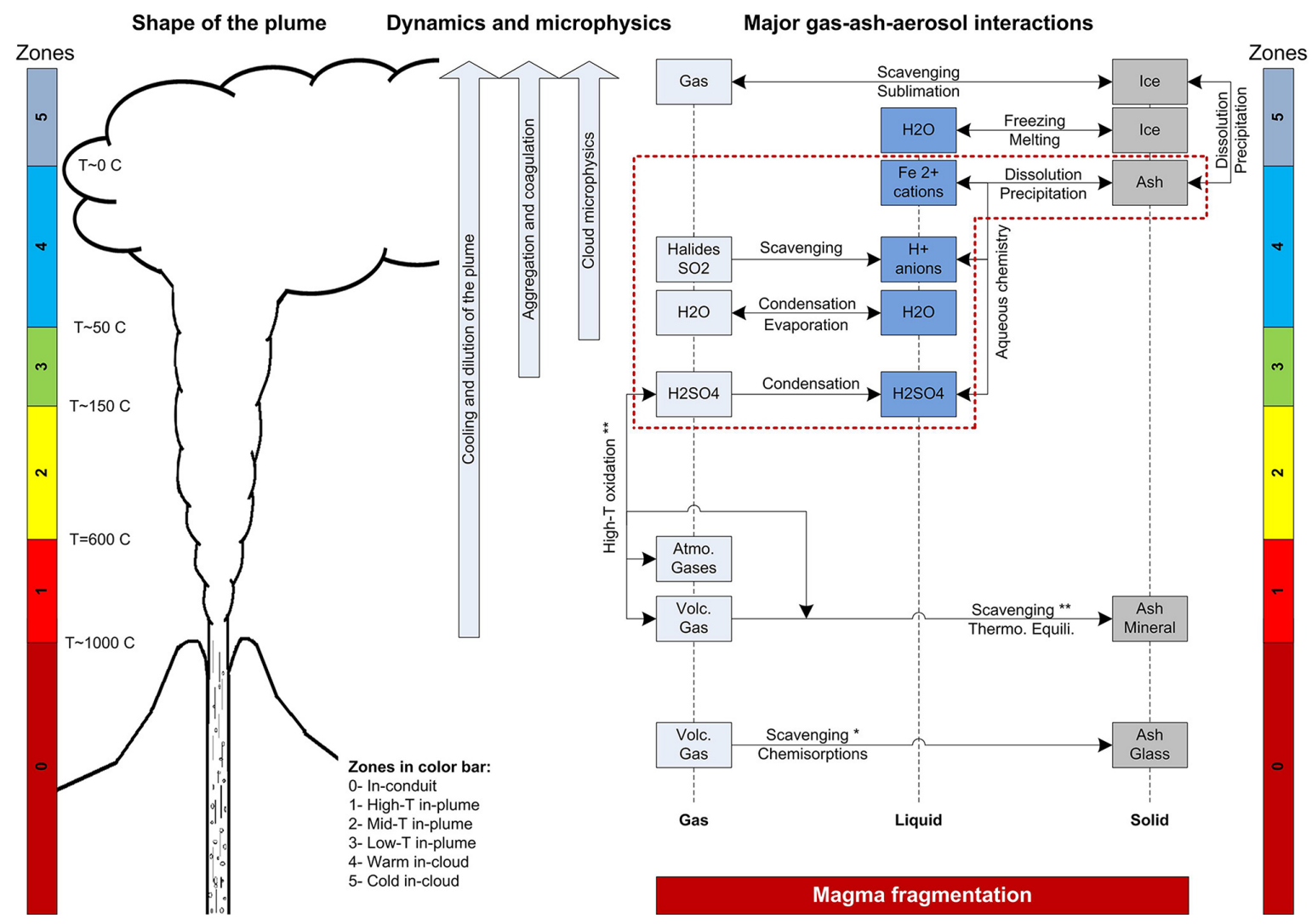

Figure 1. The interaction between ash surface, liquid coating and the surrounding gases. In high-T zones (zones 0 and 1 in the color bar) direct gas-ash interaction significantly controls the iron speciation at the ash surface. At lower temperatures, however (zones 2, 3, 4 and 5), such interactions are negligible. The formation of liquid coating at the ash surface and its interactions with the surrounding gases (scavenging) and with the ash constituents (dissolution) mainly control the ash iron mobilization. Only the processes within the red dotted line are considered in this study (* Ayris et al., 2013; ** Hoshyaripour et al., 2014).

of soluble iron-sulfate/chloride/fluoride salts on the ash surface. However, direct theoretical and experimental evidence supporting these hypotheses is required.

Previous modeling investigations on physical chemistry of volcanic eruption plumes have mainly focused on gas chemistry (e.g., Bobrowski et al., 2007), micro-physical processes like condensation, scavenging and freezing (Tabazadeh and Turco, 1993; Textor et al., 2003) and also particle aggregation (Textor et al., 2006b, a) leaving the chemical interactions of the aqueous phase and the ash surface nearly unexplored. As a result, despite advancements made by individual studies, a detailed insight into the in-plume and incloud processes that control the iron mobilization in volcanic ash remains lacking. This study therefore aims to investigate the role of these processes in ash iron mobilization through numerical modeling of the gas-ash-aerosol interactions. The main objectives are (1) to find out how much iron (ferrous and ferric) is mobilized from the ash surface (dissolved in the aqueous phase) during its vertical transport within the eruption plume and (2) to identify the favorable conditions/processes for iron mobilization in volcanic ash.
In the following sections, first the modeling concepts and methods are presented. Then the results of the simulations and their sensitivity to different parameters are discussed. Finally, the results are compared with experimental measurements and conclusions are given.

\section{Methodology}

\subsection{Modeling framework}

Figure 1 shows the main in-conduit, in-plume and in-cloud interactions of gas-ash-aerosols. In-conduit and high-T inplume zones (zones 0 and 1 in Fig. 1) have been investigated previously (Hoshyaripour et al., 2014; Ayris et al., $2013,2014)$. In this study we explore mid- and low- $\mathrm{T}$ inplume and warm in-cloud zones (zones 2, 3 and 4 in Fig. 1, respectively) through a simplified 1-D modeling approach. In other words, the lower boundary is the material leaving the high-T zone and entering zone $2\left(T=600^{\circ} \mathrm{C}\right)$ and the upper boundary is the output of zone $4\left(T \sim 0^{\circ} \mathrm{C}\right)$. Sulfuric acid condenses first (at the boundary between zones 2 and 3 ) and 
is followed almost immediately by water condensation (at the boundary between zones 3 and 4) and, thus, dissociates to $\mathrm{H}^{+}$and $\mathrm{HSO}_{4}^{-}$where we can assume that the processes are similar to conventional in-cloud processes considered in atmospheric sciences (Seinfeld and Pandis, 2006). In this study we assume that ash particles are active as condensation nuclei for sulfuric acid and water condensation (Textor et al., 2006b).

Since freezing has a significant impact on the physicochemical interactions (Textor et al., 2003), we consider two subsections for the in-cloud zone: warm (without ice/before freezing) and cold (with ice/after freezing). In the warm incloud zone, the aqueous phase scavenges the volatiles (e.g., $\mathrm{HF}, \mathrm{HCl}$ and $\mathrm{SO}_{2}$ ) from the surrounding atmosphere and also dissolves the constituents of the ash surface. These processes release cations (e.g., $\mathrm{Na}^{+}, \mathrm{Fe}^{2+}, \mathrm{Al}^{3+}$ ) and anions (e.g., $\mathrm{Cl}^{-}$, $\mathrm{SO}_{4}^{-}, \mathrm{F}^{-}$) into the liquid phase, which can react with each other generating soluble salts (Stumm and Morgan, 1996). When the temperature of the system reaches the freezing point (cold in-cloud or zone 5 in Fig. 1), ice forms at the ash surface and interacts with the surrounding atmosphere (Textor et al., 2003) and with the ash surface. This zone is, however, beyond the scope of this study.

Approximate temperature ranges associated with different zones are shown in Fig. 1 and discussed in Sect. 3. It is noteworthy that these boundaries can slightly change according to the atmospheric conditions and eruption dynamics and may also have some overlap with each other. For instance, the presence of ions in the liquid phase can cause a depression in saturation vapor pressure and shift the freezing point to lower temperatures leading to super-cooled water formation (Tabazadeh and Turco, 1993). Nevertheless, these are reasonable boundaries to better distinguish the role of different environmental conditions on gas-ash-aerosol interactions.

\subsection{Dynamics of the eruption plume}

The focus of this work is on subplinian and plinian eruption plumes that can rise up to several tens of kilometers into the atmosphere carrying huge amounts of volcanic gas and ash (Sparks et al., 1997). The ash erupted in these events could be transported thousands of kilometers downwind to reach the ocean (Duggen et al., 2010; Schmincke, 2004).

As a first order approximation, the travel time from the vent to the NBL is $150-250 \mathrm{~s}$ during which the plume temperature is lowered by $\sim 800-1000^{\circ} \mathrm{C}$ (Hort and Gardner, 2000). Thus, the mixture cooling rate is in the range of 4 $7^{\circ} \mathrm{C} \mathrm{s}^{-1}$ in the convective region of the plume. As a reference atmosphere we use the standard atmosphere having a sea level temperature of $0{ }^{\circ} \mathrm{C}$, a thermal lapse rate in the troposphere of $6.5 \mathrm{~K} \mathrm{~km}^{-1}$, a troposphere thickness of $11 \mathrm{~km}$, a $9 \mathrm{~km}$ thick tropopause, and no humidity according to US Committee on Extension to the Standard Atmosphere (1976). Since processes involving ice $\left(T<0^{\circ} \mathrm{C}\right)$ and stratospheric processes are beyond the scope of this study, we set $0^{\circ} \mathrm{C}$ plume temperature and/or $11 \mathrm{~km}$ as the upper boundary of our model. Assuming a vent altitude of $1 \mathrm{~km}$ together with the average rise time of $200 \mathrm{~s}$, we obtain an average cooling rate of $5^{\circ} \mathrm{C} \mathrm{s}^{-1}$ and an average ascent velocity of $50 \mathrm{~m} \mathrm{~s}^{-1}$ for our reference scenario, both values being well within the range suggested in the literature (cooling rate of $4-7^{\circ} \mathrm{C} \mathrm{s}^{-1}$ (Hort and Gardner, 2000) and plume ascent velocity of 40$80 \mathrm{~m} \mathrm{~s}^{-1}$; Mastin, 2007). The results discussed below are not sensitive to these particular values over a wide range of variation. At each step, temperature and elevation of the plume are calculated as prognostic variables based on these presumed rates while pressure and the kinetic and thermodynamic reaction rates are derived as diagnostic variables.

\subsection{Mass balance equations}

Concentrations of gas- and particulate-phase species in the plume are determined by solving a system of coupled mass balance equations. In its most general form, this equation is (Meskhidze et al., 2005)

$\frac{d}{\mathrm{~d} t}\left[C_{i}\right]=P_{i}-D_{i}-\alpha_{\mathrm{dep}}\left[C_{i}\right]-\alpha_{\mathrm{dill}}\left[C_{i}\right] \quad i=1, \ldots, n$

where $C_{i}$ is the concentration of species $i$ within the plume (in mol m $\mathrm{m}^{-3}$ ), $P_{i}$ and $D_{i}$ are production and destruction rates for species $i$ (in mol m $\mathrm{m}^{-3} \mathrm{~s}^{-1}$ ), $\alpha_{\text {dill }}$ is a rate constant for dilution of the plume due to mixing with ambient air, $\alpha_{\text {dep }}$ is the rate constant for loss of species contained within ash and aerosols due to fallout and deposition (wet and dry) and $n$ is the number of species considered (see Table 2). In this study we focus on calculation of the terms $P_{i}$ and $D_{i}$ via kinetic and thermodynamic reactions between gases, aqueous phase and the ash surface. The term $\alpha_{\text {dill }}$ is calculated based on the expansion of the plume due to air entrainment, temperature and pressure changes following the equation of state. As we focus on in-plume and warm in-cloud processes with a timescale of few seconds to few minutes (see Table 1), for simplicity, we can safely neglect the term $\alpha_{\text {dep }}$ for the fine ash. At each step, a system of $n$ ordinary differential equations (ODEs) is solved using the ode15s solver in MATLAB (Shampine and Reichelt, 1997). All of the considered gasphase reactions and their rate parameters are listed in the Appendix (Table A1).

Besides kinetic reactions in the gas phase, processes like condensation of sulfuric acid and water as well as the dissolution of the ash in the aqueous phase are among the most important $P_{i}$ and $D_{i}$ terms in this study which are explained below.

\subsection{Condensation}

At mid temperatures $\left(150^{\circ} \mathrm{C}<T<600^{\circ} \mathrm{C}\right)$ in the eruption plume, heterogeneous reactions involving the gas-phase and the ash material take place. Although the direct emission of $\mathrm{H}_{2} \mathrm{SO}_{4}$ is small, some of the $\mathrm{SO}_{2}$ oxidizes to $\mathrm{SO}_{3}$, which 
Table 2. The major species considered in this study.

\begin{tabular}{|c|c|}
\hline Phase & Species \\
\hline Gas & $\begin{array}{l}\mathrm{H}_{2}, \mathrm{H}_{2} \mathrm{O}, \mathrm{H}_{2} \mathrm{O}_{2}, \mathrm{SO}_{2}, \mathrm{H}_{2} \mathrm{~S}, \mathrm{SO}_{3}, \mathrm{H}_{2} \mathrm{SO}_{4}, \mathrm{CO}, \mathrm{CO}_{2}, \mathrm{O}_{3}, \mathrm{HF}, \mathrm{HCl}, \mathrm{HClO}, \mathrm{OH}, \mathrm{O}, \mathrm{H}, \mathrm{Cl}, \mathrm{ClO}, \mathrm{SO}, \mathrm{HS}, \mathrm{HSO}_{3} \text {, } \\
\mathrm{NO}, \mathrm{NO}_{2}, \mathrm{NO}_{3}, \mathrm{HNO}_{3}, \mathrm{NH}_{3}, \mathrm{~N}_{2}, \mathrm{O}_{2}\end{array}$ \\
\hline Liquid & $\begin{array}{l}\mathrm{H}_{2} \mathrm{O}, \mathrm{H}_{2} \mathrm{O}_{2}, \mathrm{OH}, \mathrm{H}_{2} \mathrm{SO}_{4}, \mathrm{SO}_{2}, \mathrm{NO}_{2}, \mathrm{NO}_{3}, \mathrm{HNO}_{3}, \mathrm{NH}_{3}, \mathrm{H}^{+}, \mathrm{OH}^{-}, \mathrm{SO}_{4}^{2-}, \mathrm{SO}_{3}^{2-}, \mathrm{HSO}_{4}^{-}, \mathrm{HSO}_{3}^{-}, \mathrm{Cl}^{-}, \mathrm{F}^{-}, \\
\mathrm{NH}_{4}^{+}, \mathrm{Fe}^{2+}, \mathrm{Fe}^{3+}, \mathrm{Al}^{3+}, \mathrm{Na}^{+}, \mathrm{Ca}^{2+}, \mathrm{Mg}^{2+}, \mathrm{Mn}^{2+}\end{array}$ \\
\hline Solid & $\begin{array}{l}\text { glass: } \mathrm{SiAl}_{0.36} \mathrm{O}_{2}(\mathrm{OH})_{1.08} \text {, fayalite: } \mathrm{Fe}_{2} \mathrm{SiO}_{4} \text {, magnetite: } \mathrm{Fe}_{3} \mathrm{O}_{4} \text {, hematite: } \mathrm{Fe}_{2} \mathrm{O}_{3} \text {, albite: } \mathrm{NaAlSi}_{3} \mathrm{O}_{8} \text {, en- } \\
\text { statite: } \mathrm{Mg}_{2} \mathrm{Si}_{2} \mathrm{O}_{6} \text {, wollastonite: } \mathrm{CaSiO}_{3} \text {, forsterite: } \mathrm{Mg}_{2} \mathrm{SiO}_{4} \text {, diopside: } \mathrm{CaMgSi}_{2} \mathrm{O}_{6}\end{array}$ \\
\hline
\end{tabular}

upon cooling readily reacts with water vapor to form vaporphase sulfuric acid $\left(\mathrm{H}_{2} \mathrm{SO}_{4}\right)$ (Hoshyaripour et al., 2012). As cooling continues, the temperature eventually drops below the dew point of the gas mixture, allowing condensation of $\mathrm{H}_{2} \mathrm{SO}_{4}$ onto the ash surfaces. Sulfuric acid has the highest dew point of all magmatic gas constituents and therefore always condenses first (Verhoff and Banchero, 1974). Details of calculating the sulfuric acid condensation rate are given in Appendix A1.

As soon as the saturation vapor pressure of water vapor is reached, liquid water condensation on the ash surface takes place. Since water vapor concentration is at least 3 orders of magnitude higher than that of $\mathrm{H}_{2} \mathrm{SO}_{4}$ in magmatic gas (Symonds et al., 1994), it readily dissociates the condensed sulfuric acid into $\mathrm{H}^{+}$and $\mathrm{HSO}_{4}^{-}$. This process can eventually lead to high concentrations of dissolved $\mathrm{H}_{2} \mathrm{SO}_{4}$ in the condensate associated with the ash and, thus, to strongly acidic $\mathrm{pH}$ values on the ash surface (Ayris and Delmelle, 2012). Rate parameters of water condensation are summarized in Appendix A2.

\subsection{Thermodynamic equilibrium}

Once the concentrations of the major species listed in Table 2 have been determined at a given time step using the equations described above, these species must be speciated into their various possible chemical forms. This is accomplished in the model by invoking thermodynamic equilibrium between the gas and liquid phases. We use the mass flux iteration method (MFI) to solve for thermodynamic equilibrium (Jacobson, 2005). MFI solves each equilibrium equation iteratively and iterates over all equations while conserving mass and charge (for more details see Jacobson, 2005). The thermodynamic equilibrium reactions considered in this study (dissolution and dissociation) and the parameters for calculating their equilibrium coefficient are presented in Appendix A3

\subsection{Ash dissolution}

The liquid film or droplets at the ash surface not only scavenge the volatiles from the gas but also dissolve the ash surface constituents. This dissolution process eventually results in the release of $\mathrm{Fe}^{2+}$ and $\mathrm{Fe}^{3+}$ from the ash in the aqueous phase (together with other cations and anions), which is central to further in-cloud processing of volcanic ash as the dissolved ions play a significant role in the aqueous chemistry. Dissolution rate in this study refers to "the steady-state temporal metal release rate divided by the stoichiometric number of moles of this metal in each mole of the dissolving mineral or glass" as defined by Oelkers (2001). In this context, steady state is defined as the conditions where dissolution is time independent and stoichiometric. Dissolution rate calculations used in this study are presented in Appendix A4.

\subsection{Size distribution of the ash}

Particle sizes $<1 \mathrm{~mm}$ are considered in this study, which corresponds to the definition of fine ash (Rose and Durant, 2009). Fine ash is thought to represent a substantial contribution (50-97 wt \%) to tephra deposits from plinian and subplinian volcanic eruptions (Rose and Durant, 2009). Particles in this size range not only have a higher surface to mass ratio (compared to the coarser particles) for interaction with the gases and aqueous phases (Delmelle et al., 2005) but can also be lifted to high altitudes and remain suspended in the atmosphere for several days before sedimentation (Sparks et al., 1997). Among others, Rose and Durant (2009) investigated the ash content of volcanic eruption plumes and suggested a typical polymodal size distribution for fine ash subdivided into 27 bins (Fig. 2a). For this binned representation of fine volcanic ash, the total number of bins between 0.01 and $1000 \mu \mathrm{m}$ (see Fig. 2a) is denoted by nclass. Each bin $i$ is considered to be monodisperse with a radius $R_{p}^{i}$ which is given by the following equation (Pirjola et al., 1999):

$$
\begin{aligned}
\log _{10}( & \left.R_{p}^{i}\right)=\log _{10}\left(r_{\min }\right) \\
& +\frac{\log _{10}\left(r_{\max }\right)-\log _{10}\left(r_{\min }\right)}{\text { nclass }}(i-1) .
\end{aligned}
$$

Here we use nclass $=27$ (Fig. 2a). Using $R_{\mathrm{p}}^{i}$ and an ash density of $2300 \mathrm{~kg} \mathrm{~m}^{-3}$ (Rose and Durant, 2009), we calculate the mass of a single particle in each bin. Assuming that near the vent approximately $3 \mathrm{wt} \%$ of the plume is gas and about $97 \mathrm{wt} \%$ is ash (Sparks et al., 1997), for each 

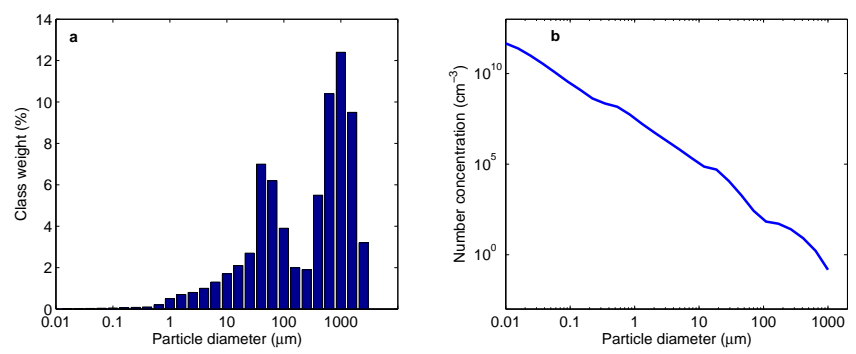

Figure 2. (a) Typical distal ash-fall particle size analysis from Rose and Durant (2009) and (b) particle number concentration calculated based on the same data.

mole of volcanic gas (with an average weight of $25 \mathrm{~g}$ ), the erupted material contains approximately $830 \mathrm{~g}$ ash, which at $T=1000^{\circ} \mathrm{C}$ and $P=1$ bar corresponds to in-plume ash concentration of $0.005 \mathrm{~g} \mathrm{~cm}^{-3}$ near the vent. Finally, using the weight percentage of each size bin (Fig. 1a), the mass of a single particle and the ash concentration calculated above, we compute the number of particles in each bin per cubic centimeter, which is shown in Fig. 2b. According to this plot, we estimate the total number concentration near the vent to be approximately $10^{12}$ particles per cubic centimeter having a total surface area of ash of $45 \mathrm{~cm}^{2} \mathrm{~cm}^{-3}$. According to previous studies, the specific surface area of fine volcanic ash is in the range $0.2-2.1 \mathrm{~m}^{2} \mathrm{~g}^{-1}$ (Delmelle et al., 2005; Mills and Rose, 2010). We find $0.9 \mathrm{~m}^{2} \mathrm{~g}^{-1}$ as the specific surface area of the fine ash in this study, which is well within the range mentioned above.

\subsection{Initial gas and ash composition}

It is known that plinian and subplinian eruptions are more likely to occur within convergent plate volcanism than other tectonic systems (Schmincke, 2004). The magmatic gases erupted from such eruptions are usually chlorine-rich (Symonds et al., 1994; Gerlach, 2004). Therefore, we consider a chlorine-rich magmatic gas composition in the reference scenario for this study (Cl-rich composition in Table 3). This composition reflects the magmatic gas and air mixture leaving the hot core of the plume $\left(T>600^{\circ} \mathrm{C}\right.$ or zone 1 in Fig. 1), and is taken as the initial condition of our modeling study which focuses on $0{ }^{\circ} \mathrm{C}<T<600^{\circ} \mathrm{C}$. Carbon and sulfur-rich magmatic gases that usually erupt from divergent plate and hot spot volcanoes, respectively (Symonds et al., 1994), are considered in the sensitivity study. We note that as volcanic gas composition can vary considerably, the compositions in Table 3 do not fully reflect all these variations but they satisfactorily represent the geochemical differences between tectonic settings (e.g., water, sulfur, carbon and halogen contents) (Gerlach, 2004).

Ash composition in this study refers to the composition of the ash surface rim with a thickness of $<100 \mathrm{~nm}$ (Achterberg et al., 2013; Gislason et al., 2011; Hoshyaripour et al., 2014).
Table 3. Average volcanic gas composition entering the mid-T zone ( $T=600{ }^{\circ} \mathrm{C}$ after mixing of $1000^{\circ} \mathrm{C}$ magmatic gas with ambient air) for convergent plate or $\mathrm{Cl}$-rich, divergent plate or $\mathrm{C}$-rich and hot spots or S-rich eruptions (concentrations are in mol \%) (Hoshyaripour et al., 2014). Cl-rich composition is used in the reference scenario. C- and S-rich compositions are used in the sensitivity study.

\begin{tabular}{lccc}
\hline Species & Cl-rich & C-rich & S-rich \\
\hline $\mathrm{H}_{2} \mathrm{O}$ & 57.70 & 50.00 & 53.50 \\
$\mathrm{CO}_{2}$ & 2.80 & 8.50 & 2.20 \\
$\mathrm{H}_{2}$ & 0.01 & 0.01 & 0.01 \\
$\mathrm{H}_{2} \mathrm{~S}$ & 0.01 & 0.01 & 0.01 \\
$\mathrm{SO}_{2}$ & 0.40 & 1.90 & 3.96 \\
$\mathrm{SO}_{3}$ & 0.87 & 3.00 & 2.85 \\
$\mathrm{H}_{2} \mathrm{SO}_{4}$ & 0.01 & 0.03 & 0.03 \\
$\mathrm{HCl}$ & 0.45 & 0.26 & 0.11 \\
$\mathrm{HF}$ & 0.04 & 0.26 & 0.12 \\
$\mathrm{CO}$ & 0.11 & 0.20 & 0.22 \\
$\mathrm{O}_{2}$ & 5.10 & 2.40 & 4.10 \\
$\mathrm{~N}_{2}$ & 32.10 & 33.40 & 33.70 \\
\hline
\end{tabular}

This rim undergoes substantial physicochemical interactions with gases and aerosols within the plume and cloud that can eventually lead to generation of a salt layer on the ash surface (Achterberg et al., 2013; Gislason et al., 2011). This salt layer is suggested to be the main source of soluble iron in volcanic ash upon contact with sea water (Duggen et al., 2010). Iron at the ash surface leaving the high-temperature zone mainly occurs as a component of glass and as Fe-carrying phases mentioned in Table 2 (Bayhurst et al., 1991; Nakagawa and Ohba, 2003). Iron release from minerals through dissolution usually involves breaking only one $\mathrm{Fe}-\mathrm{O}$ bound while in glass it may require breaking several metal-oxygen bounds through nonstoichiometric dissolution before reaching the steady state (Oelkers, 2001). Furthermore, at $\mathrm{pH}<2$, the mineral dissolution rate is similar to that of the corresponding glass (Hamilton et al., 2000). Considering this and given the limitation of data on iron release from the glass at $\mathrm{pH}<2$ and $T<25^{\circ} \mathrm{C}$, here we consider the minerals as the main source of iron within the ash particle and regard glass as a sink for protons (see Table 2).

It is suggested that iron mobilization efficiency is connected to its redox state in airborne particles (Desboeufs et al., 2001). Iron oxidation state at the ash surface is mainly controlled by the efficiency of high-temperature oxidation reactions occurring at $T>600^{\circ} \mathrm{C}$ (for more details please see Hoshyaripour et al., 2014). Thus, we consider three redox end-members: fayalite as the non-oxidized, magnetite as moderately oxidized and hematite as highly oxidized $\mathrm{Fe}$ carrying phases. Since glass is a major constituent of volcanic ash (40-80 wt \% (Blundy et al., 2006), ash in this reference scenario (hereafter referred to as Gla+Mag) consists of glass $(70 \%)$ and magnetite $(30 \%)$. Magnetite contains iron 

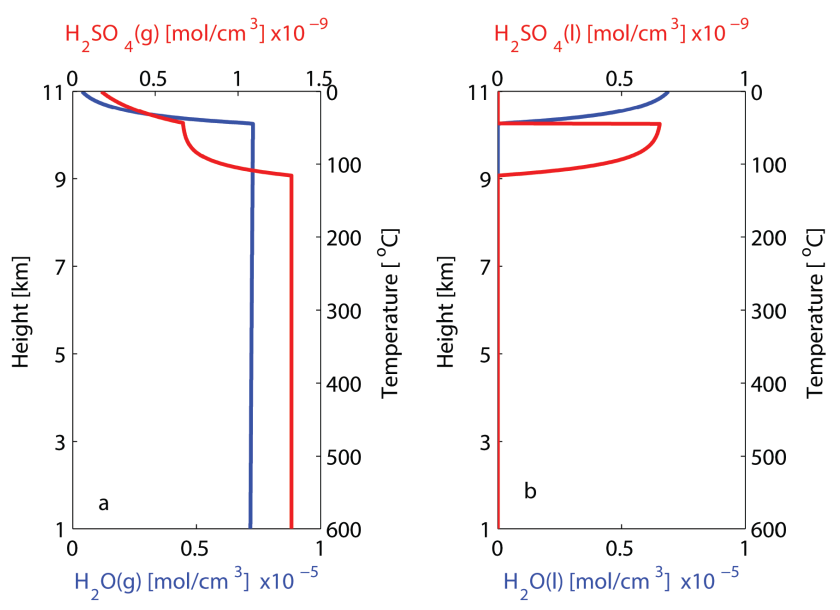

Figure 3. Vertical profile of the water (blue line) and sulfuric acid (red line) concentrations in the (a) gas and (b) aqueous phases in the eruption plume. Please note the significant differences between $\mathrm{H}_{2} \mathrm{O}$ and $\mathrm{H}_{2} \mathrm{SO}_{4}$ concentration. Vertical axes on left and right show the elevation and the plume temperature, respectively.

in both oxidation states (ferric and ferrous) and is also extensively observed in volcanic ash samples (Bayhurst et al., 1991; Gislason et al., 2011; Censi et al., 2010) making it an appropriate $\mathrm{Fe}$-carrying phase for the idealized composition in the reference scenario. The impacts of the iron oxidation state as well as other minerals on iron mobilization efficiency are discussed in a detailed sensitivity study in Sect. 4.2.

\section{Results}

\subsection{In-plume zones: water and sulfuric acid condensation}

Figure 3 shows the vertical profile of water and sulfuric acid in both vapor and liquid phases. Left and right $y$ axes show the plume elevation and the temperature, respectively. $\mathrm{H}_{2} \mathrm{SO}_{4}$ condenses first at $\sim 120^{\circ} \mathrm{C}$ (boundary between midand low-T in-plume zones). The conceptual model of Óskarsson (1980) suggests the temperature of $338^{\circ} \mathrm{C}$ as the condensation point of sulfuric acid corresponding to the dew point of pure $\mathrm{H}_{2} \mathrm{SO}_{4}$ at 1 bar (Verhoff and Banchero, 1974). However, this value is too high for volcanic plumes considering the low mixing ratio of $\mathrm{H}_{2} \mathrm{SO}_{4}$ in the gaseous phase $(<1 \mathrm{~mol} \%)$ as well as the low pressure at high elevations in the atmosphere.

The concentration of sulfuric acid droplets increases and reaches a plateau near $40^{\circ} \mathrm{C}$ (boundary between in-plume and in-cloud zones). At this temperature water vapor starts condensing, which is followed by rapid depletion of $\mathrm{H}_{2} \mathrm{SO}_{4}$ due to its dissociation in contact with liquid water (see Fig. 3a). At $T<50^{\circ} \mathrm{C}$ gaseous sulfuric acid continues to condense $\left(\mathrm{H}_{2} \mathrm{SO}_{4}(\mathrm{~g})\right.$ in Fig. 3a) and dissociate rapidly into $\mathrm{H}^{+}$and $\mathrm{HSO}_{4}^{-}$; thus, no liquid $\mathrm{H}_{2} \mathrm{SO}_{4}$ forms anymore $\left(\mathrm{H}_{2} \mathrm{SO}_{4}(\mathrm{aq})\right.$ in Fig. 3b). More than $80 \%$ of the sulfuric acid

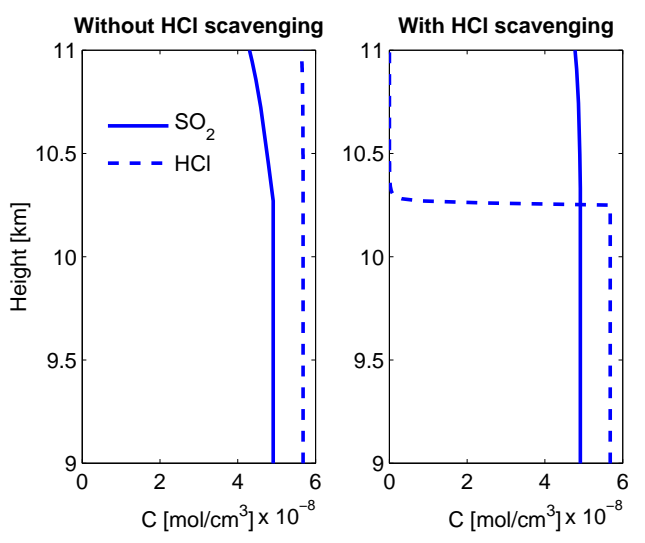

Figure 4. $\mathrm{SO}_{2}$ and $\mathrm{HCl}$ vertical profile. Left panel: without $\mathrm{HCl}$ scavenging (e.g., very low halide concentration in sulfur rich plumes); right panel: with $\mathrm{HCl}$ scavenging (e.g., $\mathrm{HCl}$-rich plumes). Note that only the height $>9 \mathrm{~km}$ is plotted here.

(all fractions given in this paper are mass fractions) condenses in the low-T in-plume and warm in-cloud zones.

We note that the eruption dynamics and gas composition can slightly vary the boundaries of mid- and low-T in-plume zones. Based on several simulations conducted in the course of this research we suggest average values of 150 and $50^{\circ} \mathrm{C}$ for $\mathrm{H}_{2} \mathrm{SO}_{4}$ and $\mathrm{H}_{2} \mathrm{O}$ condensation points in volcanic plumes, respectively. It is also noteworthy that the altitudes at which the plume reaches these temperature-dependent boundaries are significantly variable in different eruptions.

\subsection{Warm in-cloud zone}

\subsubsection{Scavenging of gases}

It has been observed that volcanic particles scavenge gas species in volcanic eruption plumes (Rose, 1977; Óskarsson, 1980). Water condensation generates a liquid coating on the ash surface (in the warm in-cloud zone) that scavenges the surrounding gases (Textor et al., 2003). Since the solubility of $\mathrm{HCl}$ is about 4 orders of magnitude higher than that of $\mathrm{SO}_{2}$, it is likely to be completely scavenged by water drops (Tabazadeh and Turco, 1993) thereby increasing the acidity of the aqueous phase and consequently decreasing $\mathrm{SO}_{2}$ scavenging which is observed in our simulations (Fig. 4, right panel). While more than $98 \%$ of the $\mathrm{HCl}$ is removed from the gas phase, only less than $5 \%$ of the $\mathrm{SO}_{2}$ is scavenged by the liquid water in the reference scenario. Therefore, in consistency with previous studies (Tabazadeh and Turco, 1993; Textor et al., 2003), high fractions of $\mathrm{SO}_{2}$ can reach the stratosphere, while a much lower fraction of $\mathrm{HCl}$ remains in the gas phase.

In general, the solubility of acid gases decreases with increasing acidity of the aqueous phase (Atkins, 1986). Since $\mathrm{HCl}$ dissolves more efficiently, it increases the acidity of the aqueous phase and hinders $\mathrm{SO}_{2}$ scavenging. Neglecting $\mathrm{HCl}$ 
Table 4. Initial composition of the volcanic ash surface in the idealized scenarios considered in this study (values in wt \%). Gla+Mag is used in the reference scenario. Other compositions are used in the sensitivity study.

\begin{tabular}{lccc}
\hline Scenario & \multicolumn{3}{c}{ Ash constituents } \\
\cline { 2 - 4 } & glass & Fe-phase $^{\mathrm{a}}$ & other minerals $^{\mathrm{b}}$ \\
\hline Gla+Mag & 70 & Mag 30 & - \\
Gla+Hem & 70 & Hem 30 & - \\
Gla+Fay & 70 & Fay 30 & - \\
Gla+Fay+Mag+Hem & 70 & Mag 10, Hem 10, Fay 10 & Min 28 \\
Gla+Mag+Min & 70 & Mag 2 & \\
\hline a The abbreviations Mag, Hem and Fay represent magnetite, hematite and fayalite, respectively. ${ }^{\mathrm{b}}$ The \\
mineral assemblage (Min) is an idealized mineralogy based on the ash composition reported in Bayhurst \\
et al. (1991): albite 72\%, enstatite 7\%, wollastonite 7\%, forsterite 7\%, and diopside 7\%.
\end{tabular}

scavenging (Fig. 4, left panel), which can also represent eruptions with very low halogen content, increases the $\mathrm{SO}_{2}$ removal from the gas phase to $15 \%$.

As noted before, dissolution of the major gas species in the aqueous phase is usually followed by their rapid dissociation (see E8-E14 in Table A2). Figure 5 shows the major products of the dissociation processes. Formation of all these anions is concurrent with $\mathrm{H}^{+}$release in the aqueous phase, which increases the acidity of the solution. Since $\mathrm{Cl}^{-}$has the highest concentration (2-9 orders of magnitude greater than other anions), $\mathrm{HCl}$ dissolution and dissociation mainly control the $\mathrm{pH}$. The final $\mathrm{pH}$ of the liquid phase in the reference scenario is 0.32 (extremely acidic), which significantly affects the ash dissolution efficiency discussed below. $\mathrm{HSO}_{4}^{-}$, $\mathrm{HSO}_{3}^{-}$and $\mathrm{F}^{-}$, which form due to dissociation of $\mathrm{H}_{2} \mathrm{SO}_{4}$, $\mathrm{SO}_{2}$ and $\mathrm{HF}$, respectively, are the most abundant species following $\mathrm{Cl}^{-}$.

\subsubsection{Ash dissolution}

The condensation, dissolution and dissociation processes in the plume acidify the liquid coating on the ash surface which dissolves the minerals and other solids (e.g., silicate glass). Figure 6 shows the dissolved iron (ferric and ferrous) from the ash in the reference scenario. The acidic liquid phase $(\mathrm{pH}<0.5)$ dissolves the ash with an average dissolution rate of $6.44 \times 10^{-12} \mathrm{~mol} \mathrm{~cm}^{-2} \mathrm{~s}^{-1}$, which is in the range of the ash dissolution rates reported in experimental studies (Delmelle et al., 2007). This process consumes $\mathrm{H}^{+}$and produces cations $\left(\mathrm{Fe}^{2+}\right.$ and/or $\left.\mathrm{Fe}^{3+}\right)$, which can also react with the anions in the aqueous phase and generate soluble iron salts. These salts can precipitate at the ash surface after water has evaporated. This is supported by the observation of a thin salt layer on volcanic ash surfaces containing chlorine, fluorine and sulfate together with iron, alkali and alkali-earth metals (Naughton et al., 1974; Delmelle et al., 2007).

Only $0.15 \mathrm{wt} \%$ of the magnetite at the ash surface is dissolved, which releases $\mathrm{Fe}^{2+}$ and $\mathrm{Fe}^{3+}$ in the aqueous phase. Although this relative quantity seems very small, one has to take into account that huge amounts of ash are usually ejected during major eruptions. Thus, an infinitesimal portion of that material has a sizable mass. This is further discussed in Sect. 5.1.

\section{Sensitivity analysis}

\subsection{Gas composition}

As discussed in Sect. 3.2, scavenging and dissociation of the volcanic gases control the $\mathrm{pH}$ of the aqueous phase. Chemical composition of the erupted gas is known to be correlated with the tectonic setting of the volcano (Symonds et al., 1994). Therefore, we use gas compositions of three types of volcanic settings: convergent plate (CP), divergent plate (DP) and hot spots (HS) (Table 3), which tend to emit Cl-, C- and S-rich gases, respectively (Symonds et al., 1994). The Clrich composition is used in the reference scenario discussed above. Table 5, left panel, shows the key parameters relevant to iron mobilization calculated during the reference and sensitivity runs. It can be seen that the dissolution rate, $\mathrm{pH}$ and total dissolved iron are in the same order of magnitude for different gas compositions and vary by 10-20\%.

In all scenarios, $\mathrm{HCl}$ is almost readily scavenged by the aqueous phase which consequently controls the $\mathrm{HF}$ and $\mathrm{SO}_{2}$ scavenging, $\mathrm{pH}$ of the liquid and finally the dissolution rate. In the Cl-rich scenario, the lowest $\mathrm{pH}$, the highest dissolved iron and dissolution rate are attained. Figure 7 shows the changes in $\mathrm{pH}$ versus $\mathrm{HCl}$ concentration in the gas phase and also the dissolution rate. It can be seen that the $\mathrm{HCl}$ scavenging controls the $\mathrm{pH}$ of the system and consequently the dissolution rate. This is in agreement with previous studies concerning the impact of $\mathrm{pH}$ on dissolution of the iron species in mineral dust (Schwertmann, 1991; Desboeufs et al., 2001) especially in presence of hydrochloric acid (Sidhu et al., 1981). Therefore, Cl-rich magmatic gases (typical gas composition at CP volcanism) could be favorable for mobilizing the ash iron through acid-mediated dissolution. This will be further discussed in Sect. 5.2. 

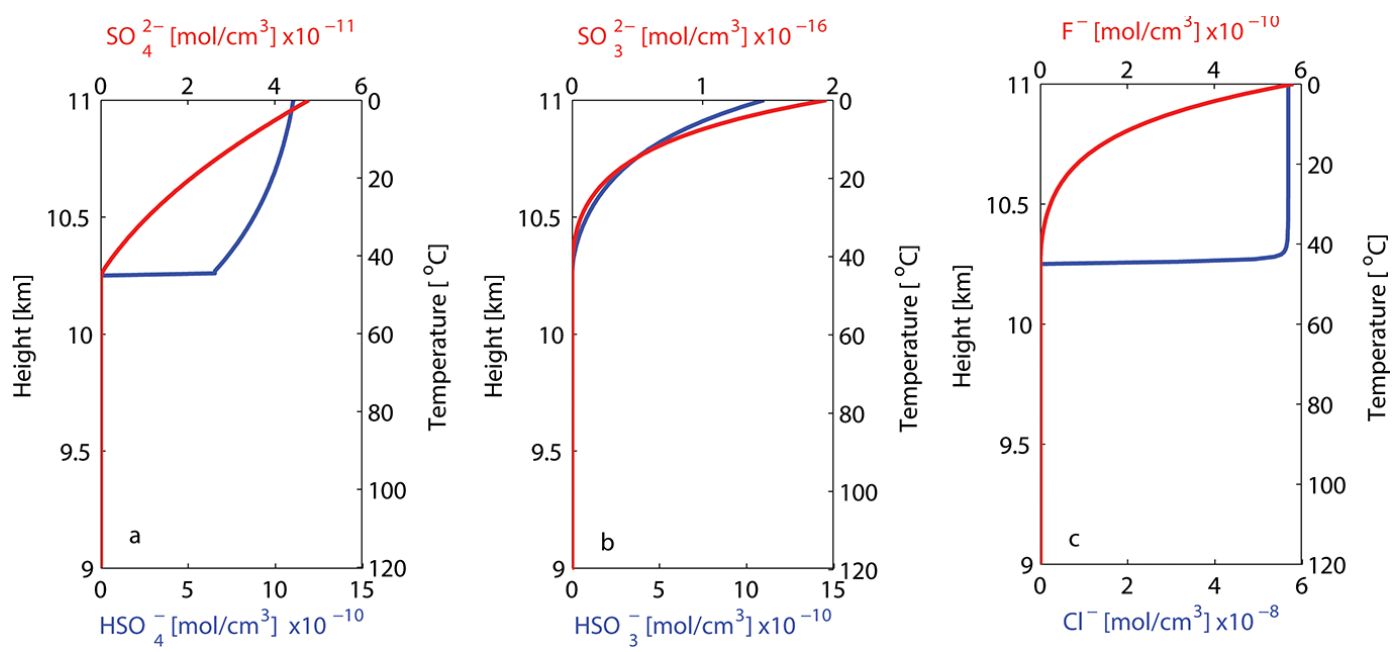

Figure 5. Vertical profile of the concentrations of major anions formed in the aqueous phase: (a) $\mathrm{HSO}_{4}^{-}$and $\mathrm{SO}_{2}^{2-}$, which form due to sulfuric acid dissociation; (b) $\mathrm{HSO}_{3}^{-}$and $\mathrm{SO}_{3}^{2-}$, which are the products of $\mathrm{SO}_{2}$ scavenging and dissociation; and (c) $\mathrm{Cl}^{-}$and $\mathrm{F}^{-}$, which are produced due to $\mathrm{HCl}$ and $\mathrm{HF}$ dissociation, respectively. Please note the different concentration scales. Vertical axes on left and right show the elevation and the plume temperature, respectively. Note that only the height $>9 \mathrm{~km}$ is plotted here.
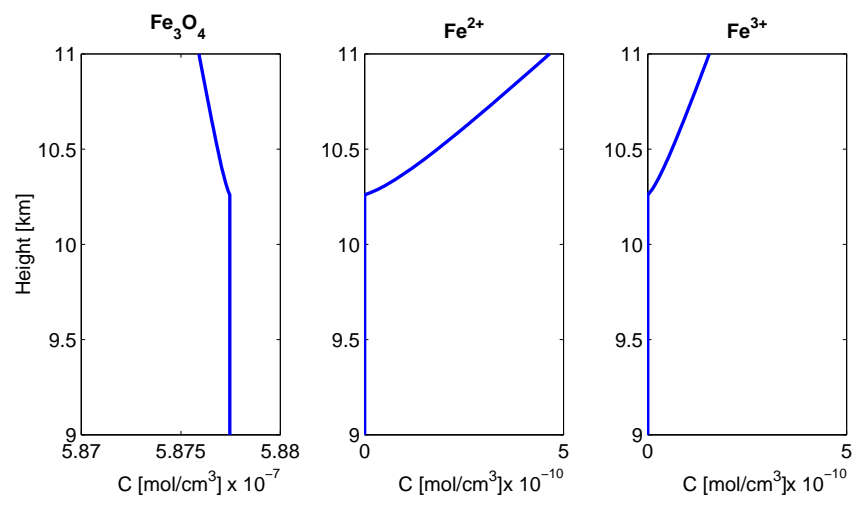

Figure 6. Vertical profile of magnetite $\left(\mathrm{Fe}_{3} \mathrm{O}_{4}\right)$, iron II and iron III concentrations. Because of relatively slow dissolution rates in the reference scenario, changes in magnetite concentration are small. Note that only the height $>9 \mathrm{~km}$ is plotted here.

\subsection{Ash composition}

One important aspect of this study is that volcanic ash contains different minerals (and not only glass and magnetite as assumed above (Nakagawa and Ohba, 2003). Therefore, we carry out a sensitivity study to evaluate the impact of changes in the ash composition on the iron mobilization efficiency. The gas compositions in these runs are constant and identical to the reference scenario (Cl-rich in Table 3).

\subsubsection{Iron redox state}

As mentioned earlier, the redox state of the iron can play a significant part in its dissolution rate (Schroth et al., 2009). Thus, we consider fayalite and hematite as the $\mathrm{Fe}^{2+}$.

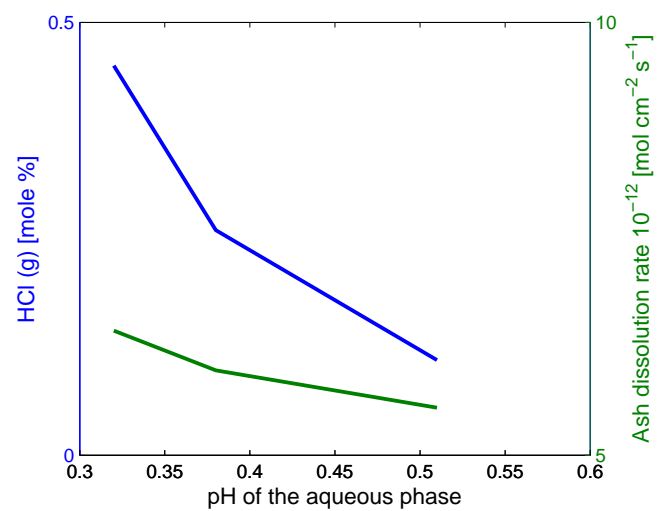

Figure 7. Correlation between $\mathrm{pH}, \mathrm{HCl}$ content of the magmatic gas and the ash dissolution rate.

and $\mathrm{Fe}^{3+}$-bearing phases, respectively (Hoshyaripour et al., 2014), to reflect the possible iron oxidation states within the ash. This leads to three additional idealized ash compositions $(\mathrm{Gla}+\mathrm{Hem}, \mathrm{Gla}+\mathrm{Fay}$ and $\mathrm{Gla}+\mathrm{Fay}+\mathrm{Mag}+\mathrm{Hem})$ shown in Table 4.

Table 5, right panel, shows the results of the sensitivity study concerning ash composition. It can be seen that when ash contains hematite instead of magnetite, the $\mathrm{pH}$ and the amount of scavenged $\mathrm{SO}_{2}$ and $\mathrm{HF}$ are not significantly different from that of the reference scenario. The dissolution rate is however 1 order of magnitude smaller than that of magnetite (the reference scenario). For the compositions including fayalite at the ash surface (compositions Gla+fay and Gla+Mag+Hem+Fay), significant changes in $\mathrm{pH}, \mathrm{SO}_{2}$ and HF scavenging are observed. Since the fayalite dissolution rate is 2 orders of magnitude greater than that of 
Table 5. Sensitivity of the key iron mobilization parameters to the changes in the volcanic gas (left panel) and ash (right panel) composition. The first column from left is the reference scenario having Cl-rich as the gas and Gla+Mag as the ash composition.

\begin{tabular}{|c|c|c|c|c|c|c|c|}
\hline \multirow{2}{*}{$\begin{array}{l}\text { Gas composition } \\
\text { Ash composition }\end{array}$} & Cl-rich & C-rich & S-rich & \multicolumn{4}{|c|}{ Cl-rich (constant) } \\
\hline & \multicolumn{3}{|c|}{ Gla+Mag (constant) } & $\mathrm{Gla}+\mathrm{Hem}$ & Gla+Fay & $\begin{array}{c}\text { Gla+Mag } \\
\text { +Hem+Fay }\end{array}$ & $\begin{array}{c}\text { Gla+Mag } \\
\text { +Min }\end{array}$ \\
\hline Final $\mathrm{pH}$ & 0.32 & 0.38 & 0.51 & 0.32 & 1.35 & 1.36 & 0.53 \\
\hline Scavenged $\mathrm{SO}_{2} \%$ & 2.86 & 2.59 & 3.60 & 2.81 & 19.30 & 19.60 & 4.12 \\
\hline Scavenged $\mathrm{HCl} \%$ & 98.51 & 98.58 & 98.41 & 98.55 & 98.48 & 98.52 & 98.50 \\
\hline Scavenged HF \% & 12.78 & 12.0 & 16.78 & 12.56 & 61.31 & 61.55 & 19.03 \\
\hline Dissolved $\mathrm{Fe}^{2+} \%$ & 0.11 & 0.08 & 0.07 & 0 & 33.0 & 13.85 & 0.38 \\
\hline Total dissolved $\mathrm{Fe} \%$ & 0.15 & 0.11 & 0.10 & 0.03 & 33.0 & 13.86 & 0.51 \\
\hline Mean dissolution rate* & 6.44 & 5.98 & 5.55 & 0.60 & 220 & 210 & 35.60 \\
\hline
\end{tabular}

* Dissolution rates are reported in mol cm ${ }^{-2} \mathrm{~s}^{-1} \times 10^{-12}$ corresponding to the average of the dissolution rates of the all ash constituents.

magnetite (reference scenario), 33 and $13.85 \%$ of the total iron is dissolved in the aqueous phase in the warm in-cloud zone for compositions Gla+fay and Gla+Mag+Hem+Fay, respectively. This enhanced dissolution efficiency of $\mathrm{Fe}^{2+}$ carrying phases is observed previously in mineral dust particles (Desboeufs et al., 2001). Such an elevated dissolution rate consumes $\mathrm{H}^{+}$more rapidly (see Table 5), reduces the acidity and consequently enhances the $\mathrm{SO}_{2}$ and $\mathrm{HF}$ scavenging. This increases the $\mathrm{SO}_{2}$ and $\mathrm{HF}$ scavenging from 2.8 and 12.5 to $19.6 \%$ and $61.55 \%$, respectively. The subsequent dissociation of the $\mathrm{SO}_{2}$ and $\mathrm{HF}$ can increase the acidity again and intensify the ash dissolution. This cycle can dominantly promote the ash iron mobilization. These results may suggest that volcanic settings that buffer iron mainly as $\mathrm{Fe}^{2+}$ in the ash surface (reduced magmatic conditions at DP and HS volcanism Hoshyaripour et al., 2014) could eventually lead to very high iron mobilization rates. This is further discussed in Sect. 5.2.

\subsubsection{Alkali and alkali-earth metals}

Dissolution of alkali and alkali-earth metals contained in the minerals and glass (usually referred to as network-modifying cations) may consume protons in the aqueous phase, thereby reducing the duration of highly acidic conditions at the ash surface and affecting the iron release (Ayris and Delmelle, 2012). Despite of the rich body of literature dealing with the natural glass dissolution (Oelkers, 2001; Oelkers and Gislason, 2001, and the references therein) a comprehensive data compilation to be used for geochemical modeling of alkali and alkali-earth metal release due to glass dissolution at $\mathrm{pH}<2$ and $T<25^{\circ} \mathrm{C}$ is unavailable. Hamilton et al. (2000) showed that under acidic conditions the dissolution behavior of the minerals is identical to that of their corresponding glass. Therefore, here we use the minerals containing alkali and alkali-earth metals assuming that they behave identical to the glass in acidic solutions (Hamilton et al., 2000). Inclusion of these minerals results in idealized ash compositions (Gla+Mag+Min) shown in Table 4.
Last column in Table 5 shows the results of the sensitivity run. The ash containing alkali and alkali-earth minerals together with glass and magnetite (Gla+Mag+Min) shows an enhanced iron mobilization efficiency compared to the reference scenario (containing only glass and magnetite). Despite the identical Fe-carrying spices in both scenarios (magnetite), inclusion of alkali and alkali-earth minerals has approximately tripled the amount of dissolved iron. This is against the common expectation that considers such metals as proton consumers that should decrease the acidity and iron mobilization efficiency (Ayris and Delmelle, 2012). The fact that such minerals dissolve faster than magnetite is also evident from the ash dissolution rate which is about 5 times greater than that of reference scenario. However, dissolution of alkali and alkali-earth metals might diminish the acidity and iron mobilization only if there is no external source to compensate the proton consumption in the aqueous phase. In the volcanic plume, $\mathrm{HF}$ and $\mathrm{SO}_{2}$ scavenging from the gas phase seem to be this external source that offset the reduced acidity. It can be seen that $\mathrm{HF}$ and $\mathrm{SO}_{2}$ scavenging are increased by approximately $50 \%$ compared to the reference scenario. In other words, consumption of the protons through dissolution of highly soluble species is immediately compensated by $\mathrm{HF}$ and $\mathrm{SO}_{2}$ absorption and dissociation in the aqueous phase, which is thermodynamically much faster than the ash dissolution (Stumm and Morgan, 1996). Therefore, existence and dissolution of other cations (alkali and alkali-earth metals) along with iron species in volcanic ash does not necessarily hamper the iron dissolution but may even enhance the iron mobilization efficiency.

\section{Discussion}

\subsection{Comparison with experimental data}

Based on the results presented above, acid-mediated dissolution of the ash seems to be the major process that mobilizes the ash iron. Dissolution and dissociation of halides $(\mathrm{HCl}$ and 


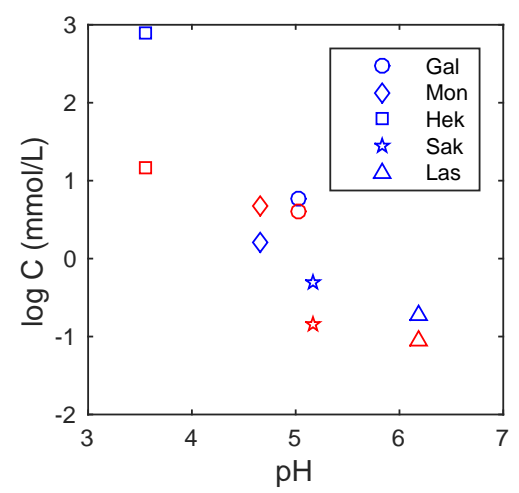

Figure 8. Concentrations of iron (blue) and halogens $(\mathrm{Cl}+\mathrm{F}$ in red) released form ash samples during the leaching experiment of Jones and Gislason (2008) as function of $\mathrm{pH}$.

$\mathrm{HF}$ ) in the aqueous phase mainly control its $\mathrm{pH}$ and, therefore, ash dissolution efficiency (see Fig. 7). The crucial role of chlorine and fluorine in enhancing ash dissolution reactions has been emphasized previously (Delmelle et al., 2007; Wolff-Boenisch et al., 2004; Moune et al., 2007). It has been suggested that the ash dissolution is most efficient within the eruption plume possibly occurring during the first minutes of the transport dictating the surface composition of ash (Moune et al., 2006; Delmelle et al., 2007). The fingerprint of these in-plume processes (namely the preferential enrichment of $\mathrm{Cl}$ and $\mathrm{F}$ on tephra surfaces) is dominant in proximal samples that deposit before being significantly affected by cloud processes (Delmelle et al., 2007). Therefore, we use proximal sample data obtained in experimental studies to evaluate the correlation between $\mathrm{pH}$, halide and iron releases from the ash. Jones and Gislason (2008) measured the concentrations and fluxes of elements into deionized water through leaching experiments on eight unhydrated volcanic ash samples. Five ash samples (Galeras, Montserrat, Hekla, Sakura-jima and Lascar) are selected for evaluation in this study since they are collected $<15 \mathrm{~km}$ away from the vents and, thus, could be considered as proximal samples (for more details see Jones and Gislason, 2008).

Figure 8 shows concentrations of iron and halides $(\mathrm{Cl}+\mathrm{F})$ released from ash samples as a function of $\mathrm{pH}$. This figure unambiguously shows that the higher the chlorine and fluorine concentrations, the lower the $\mathrm{pH}$ and the higher the iron releases are. The absolute $\mathrm{pH}$ values in this figure are higher than those calculated in this study (Table 5) because ash samples are influenced by freezing-melting and precipitationevaporation cycles as well by aqueous chemistry during further in-cloud processing, which are not considered in our model simulations. All these processes may change the absolute $\mathrm{pH}$ values and also iron and halide speciation (Desboeufs et al., 2001). However, their relative quantities still buffer the correlation of $\mathrm{pH}$, iron dissolution efficiency and the chlorine and fluorine concentrations.
The ash sample from Hekla has a 2 orders of magnitude higher iron release than the other samples. The reason of this exceptional iron release from Hekla ash stems mainly from its unusual composition (erupted gas and ash composition), with a combined hot spot and divergent plate margin magma source coupled with high fluorine in the eruptive products (Óskarsson, 1980; Moune et al., 2006). Petrological estimates suggest reduced conditions for the basaltic Hekla magma prior to eruption (Moune et al., 2007). As a result, the observed mineral phases in the Hekla ash include olivine, clinopyroxene and spinel (Höskuldsson et al., 2007), which is close to the Gla+Fay and Gla+Fay+Mag+Hem ash compositions in Table 5. As discussed above, the weight percentage of the dissolved iron is mainly governed by two independent factors: halogen content of the gas and iron oxidation state in the ash surface. Thus, having $\mathrm{Fe}^{2+}$-carrying species and high halide content concurrently in the Hekla eruption plume can mobilize $13.85-33 \%$ of the total iron at the ash surface. Since there is no evidence for such exceptional conditions for the other eruptions considered in Fig. 8, we use the range of $0.03-0.15 \%$ (according to the ash compositions Gla+Mag and Gla+Hem together with the Cl-rich gas composition in Table 5) as the weight percentage of mobilized surficial iron in these samples. To estimate the iron release from the ash $R_{\mathrm{Fe}}$ (mol g${ }^{-1}$ ash) based on proposed theoretical values in this study, the following equation is used:

$$
R_{\mathrm{Fe}}=C_{\mathrm{Fe}} l_{\mathrm{s}} D_{i} / M_{\mathrm{Fe}},
$$

where $C_{\mathrm{Fe}}$ is the iron weight percentage in the bulk composition, $l_{\mathrm{S}}$ is the ash surface layer weight ratio (1-5\% of the total ash mass), $D_{i}$ is the weight percentage of the dissolved iron according to Table 5 and $M_{\mathrm{Fe}}$ is the molar weight of iron $\left(55.84 \mathrm{~g} \mathrm{~mol}^{-1}\right)$. Considering both experimental (Gislason et al., 2011) and theoretical (Hoshyaripour et al., 2014) estimates concerning the thickness of ash surface layer, we assume the thickness of the ash rim to be on average $10 \mathrm{~nm}$. Having a specific surface area of $1.1-2.1 \mathrm{~m}^{2} \mathrm{~g}^{-1}$ (Delmelle et al., 2005), the surface rim in each gram ash with density of $2500 \mathrm{~kg} \mathrm{~m}^{-3}$ has the weight of approximately $0.01-0.05 \mathrm{~g}$ or $1-5 \%$ of the total ash mass. This range is used here for $l_{\mathrm{s}}$. The $R_{\mathrm{Fe}}$ values calculated in this study and also measured by Jones and Gislason (2008) are shown in Table 6. The measured iron release from four ash samples is satisfactorily in the calculated range based on Eq. (3). Only the Galeras ash is slightly outside the range. Therefore, according to Fig. 8 and Table 6 there is a good overall agreement between the results of the theoretical approach of this study and experimental measurements of ash iron release. This confirms the strong connection between iron release from ash with the halide concentrations and $\mathrm{pH}$.

The relative quantity of the mobilized iron discussed above may seem minor (especially the $0.03-0.15 \%$ in the reference scenario). But this needs to be considered in the context of the massive ash content of the volcanic ejecta. For instance, 
Table 6. Calculated and measured iron release from the volcanic ash surface.

\begin{tabular}{lccccc}
\hline Volcano & Eruption year & $\begin{array}{c}C_{\mathrm{Fe}}^{\mathrm{a}} \\
(\mathrm{wt} \%)\end{array}$ & $\begin{array}{c}D_{i} \text { range } \\
(\mathrm{wt} \%)\end{array}$ & $\begin{array}{c}\text { Measures } R_{\mathrm{Fe}} \mathrm{a}^{\mathrm{a}} \\
\left(\mu \mathrm{mol} \mathrm{g}^{-1} \text { ash }\right)\end{array}$ & $\begin{array}{c}\text { Calculated } R_{\mathrm{Fe}}{ }^{\mathrm{b}} \\
\left(\mu \mathrm{molg}{ }^{-1}\right.\end{array} \mathrm{ash}^{2}$ \\
\hline Galeras, Colombia & 2005 & 7.47 & $0.03-0.15$ & 0.12 & $0.004-0.1$ \\
Montserrat, Caribbean & 2003 & 6.57 & $0.03-0.15$ & 0.04 & $0.003-0.08$ \\
Hekla, Iceland & 2000 & 11.86 & $13.85-33.0$ & 10.85 & $2.93-34.94$ \\
Sakura-jima, Japan & 1994 & 7.96 & $0.03-0.15$ & 0.03 & $0.004-0.10$ \\
Lascar, Chile & 1993 & 6.0 & $0.03-0.15$ & 0.01 & $0.003-0.08$ \\
\hline
\end{tabular}

${ }^{\mathrm{a}}$ Extracted from table 2 of Jones and Gislason (2008). ${ }^{\mathrm{b}}$ Based on values reported in Table 5.

the eruption of Kasatochi Volcano in 2008 produced approximately $6 \times 10^{11} \mathrm{~kg}$ of ash (Langmann et al., 2010) containing $5-10 \mathrm{wt} \%$ iron in the bulk composition (Wang et al., 2010). Assuming the mass of the ash surface rim as approximately $1-5 \%$ of the total mass, the surface rim of the ash from the Kasatochi eruption carries approximately $0.6-3 \times 10^{8} \mathrm{~kg}$ iron. Mobilization of $0.03-0.15 \%$ of the iron at the ash surface (as in the reference scenario) according to Eq. (3) means $5-134 \mathrm{nmol} \mathrm{Fe} \mathrm{g}^{-1}$ ash which is close to the measured iron released from Kasatochi ash $\left(61-81 \mathrm{nmol} \mathrm{Fe}^{-1}\right)$ reported by Olgun et al. (2013b). Although the fate and speciation of the dissolved iron depend on further in-cloud processes, the calculations above indicate that even a very small percentage of mobilized iron in the ash means a huge mass with potentially significant impacts on the receiving environment.

\subsection{Favorable conditions for iron mobilization}

Duggen et al. (2010) and later Olgun et al. (2011) reported a correlation between tectonic setting of volcanoes and the ash iron fertilization suggesting the arc volcanism (CP) as the favorable setting for soluble iron production compared to non-arc volcanoes (DP and HS). However, in their comparisons, they neglected the exceptionally high iron release from the ash of the Hekla eruption in 2000 which is located in a non-arc setting. The distribution of their samples seems also statistically biased toward CP volcanism as they analyzed 40 samples from such volcanoes and only 4 samples form other settings. As mentioned earlier, emissions from arc volcanism are known to be Cl-rich (Symonds et al., 1994). Thus, according to the results of this study, development of highly acidic coatings on the ash surface is very likely in $\mathrm{CP}$ eruptions resulting in elevated ash dissolution rates.

The efficiency of acid-mediated dissolution, however, depends not only on acidity and temperature but also on the mineral composition (Schwertmann, 1991; Blesa et al., 1994). $\mathrm{Fe}^{2+}$-carrying phases (reduced iron minerals) show 1-2 orders of magnitude higher dissolution rates under acidic conditions (see Sect. 4.2 and also Palandri and Kharaka, 2004). Non-arc volcanic settings (DP and HS) typically record reduced conditions in comparison to the $\mathrm{CP}$ setting (Lindsley, 1991). Thus, DP and HS settings could be fa- vorable for iron fertilization too with respect to iron oxidation state. The Hekla eruption in 2000, Iceland, had both reduced magmatic conditions (as usual for DP and HS) and high halide content (as usual for CP) (Moune et al., 2009) which leads to an exceptional iron release behavior.

Therefore, our results suggest that attributing the fertilization potential of the ash to the tectonic setting of a volcano is an inconsistent hypothesis. Instead, elevated halogen content in the gas $(\mathrm{HCl}$ and $\mathrm{HF})$ and reduced conditions in the magma (that essentially modulate the $\mathrm{pH}$ and iron redox state, respectively) seem to be the favorable conditions for ash iron mobilization. This is comparable with the results of the mineral dust studies that report a strong correlation between the water-soluble fraction of Fe-carrying aerosols, $\mathrm{pH}$ and the iron redox state (Sidhu et al., 1981; Desboeufs et al., 2001).

\section{Conclusion and implications}

The 1-D numerical model introduced in this study simulates the heterogeneous interactions of the gases, liquid phase and the ash surface within the volcanic eruption plume in the temperature range of $600-0{ }^{\circ} \mathrm{C}$. It provides the first theoretical constraints on the impacts of such processes on ash iron mobilization. Although determining the fate of the dissolved species in the aqueous phase requires further investigations, our first attempt reveals that the ash dissolution can even modulate the gas scavenging efficiency through changing the $\mathrm{pH}$ of the liquid coatings. Therefore, ash needs to be considered as a reactive component in modeling the physical chemistry of volcanic eruption plumes and clouds. This study constitutes a base for the future elaboration of an ash and aerosol evolution scheme in volcanic plumes.

According to the results, in halogen-rich eruption plumes, dissolution and dissociation of $\mathrm{HCl}$ (and partly HF) mainly controls the $\mathrm{pH}$ of the aqueous phase at the ash surface in the warm in-cloud zone. For these volcanoes, $\mathrm{SO}_{2}$ scavenging by liquid particles could be negligible and seems to be more efficient in contact with ice particles as suggested by Textor et al. (2003). On the other hand, during carbon- and sulfur-rich eruptions (DP and $\mathrm{HS}$ volcanism, respectively) $\mathrm{SO}_{2}$ scavenging by the aqueous phase is more likely and could be the main 
process controlling the $\mathrm{pH}$ and, thus, the ash dissolution. The sensitivity analysis also revealed that changes in the halogen content of the gas phase modifies the iron mobilization efficiency by 10-20\% while changes in the iron redox state at the ash surface may result in 1-2 orders of magnitude difference in the mobilization efficiency.

Under acidic $\mathrm{pH}$ conditions, the dissolution of iron oxides could be greatly enhanced in the ice phase compared to in water (Jeong et al., 2012). As dissolution consumes $\mathrm{H}^{+}$, it reduces the acidity and can accelerate the $\mathrm{SO}_{2}$ scavenging by ice (Textor et al., 2003). Therefore, sulfur scavenging by volcanic ash and aerosols seems to be less efficient during mid- and low-T in-plume as well as the warm in-cloud processes. Instead, high-T (both in-conduit (Ayris et al., 2013) and in-plume (Hoshyaripour et al., 2014)) and cold in-cloud zones (Textor et al., 2003) appear to be more relevant to the sulfur scavenging. These effects should be considered in interpreting the results of leaching experiments on ash deposits to distinguish the fingerprint of the in-plume and in-cloud processes on the ash surface composition.

The local, regional and global impacts of volcanism upon the Earth system (atmosphere, hydrosphere, pedosphere, cryosphere and biosphere) are initially induced by the physicochemical properties of the ash and gas. Several lines of evidence indicate that the in-plume and in-cloud processes can significantly alter these properties and, thus, their impacts on the Earth system. For instance, the efficiency of $\mathrm{HCl}, \mathrm{SO}_{2}$ and $\mathrm{HF}$ scavenging by volcanic aerosols could be influenced by the proton consumption through ash dissolution. This can modulate the amount of volcanic gases that reach the middle atmosphere. Therefore, the in-plume and in-cloud processing of the volcanic ejecta need to be considered in future investigations on, for example, injection of volcanic gases into the stratosphere and its climatic impacts.
In addition to the ash and gas composition, which are largely governed by the composition of the source magma, other factors can considerably vary the efficiency of iron mobilization at the ash surface. Particle size distribution basically controls the surface area to mass ratio, which is a key parameter for condensation, scavenging and dissolution processes. Smaller particles with lower surface area to mass ratios tend to be more efficient agents in these processes (Rose, 1977). Although magma fragmentation dictates the initial ash size distribution (Rose and Durant, 2009), in-plume and in-cloud particle aggregation can significantly alter it (Brown et al., 2012). The influences of aggregation on ash size distribution and, thus, on physical chemistry of the ash-gasaerosol interactions could be notable and is the topic of ongoing investigations. Another important factor is the time that ash particles spend in different zones of the plume and cloud. Dynamics of the eruption as well as the ambient environmental conditions govern the spatial and temporal evolution of the eruption plume and cloud (Sparks et al., 1997). Impacts of these factors on ash chemistry could be constrained by incorporating the chemistry modules into dynamical models of volcanic eruption plumes.

In this study we used idealized ash compositions which satisfactorily replicate the behavior of the ash in the real system. However, upon availability of data, real ash surface mineralogy and compositions (within $100 \mathrm{~nm}$ rim) should be used in future studies. Moreover, iron release from glass components of the volcanic ash need to be studied experimentally in order to obtain detailed reaction rate parameters to be used in numerical modeling investigations.

Aqueous chemistry, stratospheric chemistry and all the processes involving ice could also significantly affect the fate of the dissolved iron (e.g., $\mathrm{SO}_{2}$ oxidation catalyzed by $\mathrm{Fe}$ ions; Harris et al., 2013). Therefore, further modeling and experimental studies are necessary to comprehend the impact of in-cloud processes on iron chemistry in volcanic ash. 


\section{Appendix A: Formulations of the processes}

\section{A1 Sulfuric acid condensation}

The dew point of sulfuric acid is calculated using the following equation (Jeong and Levy, 2012):

$$
\begin{aligned}
& \frac{1}{T_{\text {dew }}}=2.27 \times 10^{-5}-2.94 \times 10^{-7} \cdot \ln \left(P_{\mathrm{H}_{2} \mathrm{O}}\right) \\
& -8.58 \times 10^{-6} \cdot \ln \left(P_{\mathrm{H}_{2} \mathrm{SO}_{4}}\right) \\
& +6.2 \times 10^{-6} \cdot\left\{\ln \left(P_{\mathrm{H}_{2} \mathrm{O}}\right) \cdot \ln \left(P_{\mathrm{H}_{2} \mathrm{SO}_{4}}\right)\right\}
\end{aligned}
$$

where $P_{\mathrm{H}_{2} \mathrm{O}}$ and $P_{\mathrm{H}_{2} \mathrm{SO}_{4}}$ are partial pressures of the water vapor and sulfuric acid (in $\mathrm{mm} \mathrm{Hg}$ ), respectively. When the temperature of the plume drops below $T_{\text {dew }}$, sulfuric acid condenses onto the ash particles. In this study the FuchsSutugin interpolation formula is used to describe the condensation rate of $\mathrm{H}_{2} \mathrm{SO}_{4}$ molecules to the ash particles (Fuchs and Sutugin, 1970). The single particle condensation coefficient is given by

$$
K_{\mathrm{FS}}=\alpha K_{\mathrm{kin}}\left[1+\frac{3 \alpha}{4 K n} \times\left(1-0.623 \frac{K n}{1+K n}\right)\right]^{-1},
$$

where $\alpha$ is the accommodation coefficient of $\mathrm{H}_{2} \mathrm{SO}_{4}(\sim 1$ in this study (Clement et al., 1996)); $K_{\text {kin }}$ is the kinetic condensation coefficient $\left(\pi R_{\mathrm{p}}^{2} c_{b}\right) ; c_{b}$ is the average thermal velocity of $\mathrm{H}_{2} \mathrm{SO}_{4}$ gas molecules $\left([8 \mathrm{kT} / \pi M]^{1 / 2}\right) ; K n$ is the particle Knudsen number $\left(l / R_{\mathrm{p}}\right) ; l$ is the mean free path of $\mathrm{H}_{2} \mathrm{SO}_{4}$ molecules $\left(3 D_{b} / c_{b}\right) ; D_{b}$ is the $\mathrm{H}_{2} \mathrm{SO}_{4}$ diffusion coefficient $\left(0.08 \mathrm{~cm}^{2} \mathrm{~s}^{-1}\right) ; T$ is the absolute temperature in kelvin; $k$ is the Boltzmann constant; $M$ is the mass of $\mathrm{H}_{2} \mathrm{SO}_{4}$ molecule; and $R_{\mathrm{p}}$ is the particle radius.

With respect to the previous section, we calculate the condensation rate onto a polydisperse ash distribution. In which case the condensation coefficient $X_{\mathrm{c}}$ is defined as

$X_{\mathrm{c}}=\int_{0}^{\infty} K_{\mathrm{FS}}\left(R_{\mathrm{p}}\right) n\left(R_{\mathrm{p}}\right) \mathrm{d} R_{\mathrm{p}}$

where $n\left(R_{\mathrm{p}}\right) \mathrm{d} R_{\mathrm{p}}$ is the concentration of particles with radius between $R_{\mathrm{p}}$ and $R_{\mathrm{p}}+\mathrm{d} R_{\mathrm{p}}$ according to Rose and Durant (2009). The condensation rate onto a polydisperse distribution is finally given by

$\mathrm{CS}=\int_{0}^{\infty} K_{\mathrm{FS}}\left(R_{\mathrm{p}}\right) n\left(R_{\mathrm{p}}\right) \times\left[N_{\mathrm{g}}-N_{\mathrm{g}}^{\mathrm{e}}\left(R_{\mathrm{p}}\right)\right] \mathrm{d} R_{\mathrm{p}}$,

where $N_{\mathrm{g}}$ is the $\mathrm{H}_{2} \mathrm{SO}_{4}$ vapor pressure in the gas phase and $N_{\mathrm{g}}^{\mathrm{e}}\left(R_{\mathrm{p}}\right)$ is the equilibrium vapor pressure over a particle with radius $R_{\mathrm{p}}$. In a volcanic eruption plume, $N_{\mathrm{g}}^{\mathrm{e}}\left(R_{\mathrm{p}}\right)$ is negligible in comparison to $N_{\mathrm{g}}$. Hence, Eq. (A4) simplifies to

$\mathrm{CS}=X_{\mathrm{c}} N_{\mathrm{g}}$

\section{A2 Water condensation}

The mass flux of water condensing onto a single, spherical particle with radius $R_{\mathrm{p}}$ is given by (Jacobson, 2005)

$$
K_{\mathrm{FW}}=\frac{4 \pi D_{\mathrm{v}}\left(p_{\mathrm{v}}-p_{\mathrm{v}, \mathrm{s}}\right)}{\frac{D_{\mathrm{v}} L_{\mathrm{e}} p_{\mathrm{v}, \mathrm{s}}}{k_{a} T}\left(\frac{L_{\mathrm{e}}}{R_{\mathrm{v}} T}-1\right)+R_{\mathrm{v}} T},
$$

where $D_{\mathrm{v}}$ is the molecular diffusion coefficient of water vapor in air $\left(0.234 \mathrm{~cm}^{2} \mathrm{~s}^{-1}\right) ; p_{\mathrm{v}}$ is the vapor pressure of water vapor in plume (in $\mathrm{hPa}$ ); $p_{\mathrm{v}, \mathrm{s}}$ is the saturation vapor pressure at the particle surface $\left(6.112 \exp \left(17.67 T_{\mathrm{c}} /\left(T_{\mathrm{c}}+243.5\right)\right)\right) ; T_{\mathrm{c}}$ is the temperature in degrees Celsius; $L_{\mathrm{e}}$ is the latent heat of water evaporation $\left(2260 \mathrm{~J} \mathrm{~g}^{-1}\right) ; R_{\mathrm{V}}$ is the gas constant for water vapor $\left(461.40 \mathrm{~J} \mathrm{~kg}^{-1} \mathrm{~K}^{-1}\right) ; k_{\mathrm{a}}$ is the thermal conductivity of moist air $\left(\approx k_{\mathrm{d}}\left[1-\left(1.17-1.02 \frac{k_{\mathrm{v}}}{k_{\mathrm{d}}}\right) \frac{n_{\mathrm{v}}}{n_{\mathrm{v}}+n_{\mathrm{d}}}\right]\right) ; k_{\mathrm{d}}$ and $k_{\mathrm{v}}$ are the thermal conductivity of dry air and water vapor, respectively; and $n_{\mathrm{d}}$ and $n_{\mathrm{v}}$ are the number of moles of dry air and water vapor, respectively.

Finally, the condensation rate of water onto a polydisperse aerosol distribution is calculated by

$$
\mathrm{CW}=\int_{0}^{\infty} K_{\mathrm{FW}}\left(R_{\mathrm{p}}\right) n\left(R_{\mathrm{p}}\right) \mathrm{d} R_{\mathrm{p}}
$$

\section{A3 Thermodynamic equilibrium}

Thermodynamic equilibrium reactions are shown in Table A2. The equilibrium coefficient $\left(K_{\text {eq }}\right)$ for each reaction at temperature $T$ is calculated by (Jacobson, 2005)

$$
K_{\text {eq }}(T)=A \exp \left\{B\left(\frac{T_{0}}{T}-1\right)+C\left(1-\frac{T_{0}}{T}+\ln \frac{T_{0}}{T}\right)\right\},
$$

where $T_{0}=298.15 \mathrm{~K}$. The $A, B$ and $C$ values are listed in Table A2.

\section{A4 Ash dissolution}

The dissolution rate of the mineral species $i$ is calculated based on a simplified formulation proposed by Palandri and Kharaka (2004):

$\log D_{i}=\log k_{i}-n_{i} \cdot \mathrm{pH}$

where $D_{i}$ is the dissolution rate (in mol m${ }^{-2} \mathrm{~s}^{-1}$ ); $\log k_{i}$ is the $\log$ rate constant computed at $25^{\circ} \mathrm{C}$ and $\mathrm{pH}=0$; and $n$ is the reaction order with respect to $\mathrm{H}^{+}$. Table $\mathrm{A} 3$ shows the rate parameters used in this study for different ash constituents. These parameters are accurate to a first-order approximation over the range of acidic $\mathrm{pH}$ (Palandri and Kharaka, 2004). We note that the dissolution rates used here (Eq. A9) are temperature independent, which is a valid assumption if one considers the short residence time of particles at a certain temperature in the eruption column (few seconds). 
Table A1. Gas-phase reactions and rate coefficients.

\begin{tabular}{lllc}
\hline No. & Reaction & Rate coefficient & Reference* \\
\hline $\mathrm{R} 1$ & $\mathrm{SO}_{2}+0.5 \mathrm{O}_{2} \rightarrow \mathrm{SO}_{3}$ & $1.3 \times 10^{-33}(600 / T)^{3.6}$ & 1,2 \\
$\mathrm{R} 2$ & $\mathrm{SO}_{3}+\mathrm{O}_{3} \rightarrow \mathrm{SO}_{3}+\mathrm{O}_{2}$ & $3.0 \times 10^{-12} \mathrm{e}^{-7100 / T}$ & 1 \\
$\mathrm{R} 3$ & $\mathrm{SO}_{2}+\mathrm{OH} \rightarrow \mathrm{HSO}_{3}$ & $4.0 \times 10^{-31}(300 / T)^{3.3}$ & 1,2 \\
$\mathrm{R} 4$ & $\mathrm{HSO}_{3}+\mathrm{O}_{2} \rightarrow \mathrm{SO}_{3}+\mathrm{HO}_{2}$ & $1.3 \times 10^{-12} \mathrm{e}^{-330 / T}$ & 1,2 \\
$\mathrm{R} 5$ & $\mathrm{SO}_{3}+\mathrm{H}_{2} \mathrm{O} \rightarrow \mathrm{H}_{2} \mathrm{SO}_{4}$ & $6.0 \times 10^{-15}$ & 3,2 \\
$\mathrm{R} 6$ & $\mathrm{H}_{2} \mathrm{~S}+\mathrm{OH} \rightarrow \mathrm{HS}+\mathrm{H}_{2} \mathrm{O}$ & $6.3 \times 10^{-12} \mathrm{e}^{-80 / T}$ & 1,2 \\
$\mathrm{R} 7$ & $\mathrm{HS}+\mathrm{O}_{2} \rightarrow \mathrm{SO}+\mathrm{OH}$ & $4.0 \times 10^{-19}$ & 3 \\
$\mathrm{R} 8$ & $\mathrm{SO}+\mathrm{O}_{2} \rightarrow \mathrm{SO}+\mathrm{O}$ & $2.1 \times 10^{-13} \mathrm{e}^{-2280 / T}$ & 1,2 \\
$\mathrm{R} 9$ & $\mathrm{HCl}+\mathrm{OH} \rightarrow \mathrm{Cl}+\mathrm{H}_{2} \mathrm{O}$ & $2.4 \times 10^{-12} \mathrm{e}^{-330 / T}$ & 1,2 \\
$\mathrm{R} 10$ & $\mathrm{HClO}+\mathrm{O} \rightarrow \mathrm{ClO}+\mathrm{OH}$ & $1.0 \times 10^{-11} \mathrm{e}^{-1300 / T}$ & 1,2 \\
$\mathrm{R} 11$ & $\mathrm{NO}+\mathrm{O}_{3} \rightarrow \mathrm{NO}_{2}+\mathrm{O}_{2}$ & $1.8 \times 10^{-12} \mathrm{e}^{-1370 / T}$ & 1,3 \\
$\mathrm{R} 12$ & $\mathrm{OH}+\mathrm{O} \rightarrow \mathrm{H}_{+} \mathrm{O}_{2}$ & $2.3 \times 10^{-11} \mathrm{e}^{110 / T}$ & 1,2 \\
$\mathrm{R} 13$ & $\mathrm{OH}+\mathrm{O}_{3} \rightarrow \mathrm{HO}_{2}+\mathrm{O}_{2}$ & $1.9 \times 10^{-12} \mathrm{e}^{-1000 / T}$ & 2,3 \\
$\mathrm{R} 14$ & $\mathrm{OH}+\mathrm{H}_{2} \rightarrow \mathrm{H}_{2} \mathrm{O}+\mathrm{H}$ & $7.7 \times 10^{-12} \mathrm{e}^{-2100 / T}$ & 1,2 \\
$\mathrm{R} 15$ & $\mathrm{OH}+\mathrm{OH} \rightarrow \mathrm{H}_{2} \mathrm{O}+\mathrm{O}$ & $4.2 \times 10^{-12} \mathrm{e}^{-240 / T}$ & 1,3 \\
\hline
\end{tabular}

* (1) Sander et al. (2011), (2) Jacobson (2005), (3) Seinfeld and Pandis (2006).

Table A2. Equilibrium reactions and rate coefficients (Jacobson, 2005).

\begin{tabular}{|c|c|c|c|c|}
\hline No. & Reaction & A & B & $\mathrm{C}$ \\
\hline E1 & $\mathrm{SO}_{2}(\mathrm{~g}) \rightleftharpoons \mathrm{SO}_{2}(\mathrm{aq})$ & 1.22 & 10.55 & 0 \\
\hline E2 & $\mathrm{H}_{2} \mathrm{O}_{2}(\mathrm{~g}) \rightleftharpoons \mathrm{H}_{2} \mathrm{O}_{2}(\mathrm{aq})$ & $7.45 \times 10^{4}$ & 22.21 & 0 \\
\hline E3 & $\mathrm{NO}_{2}(\mathrm{~g}) \rightleftharpoons \mathrm{NO}_{2}(\mathrm{aq})$ & $1.00 \times 10^{-2}$ & 8.38 & 0 \\
\hline $\mathrm{E} 4$ & $\mathrm{NO}_{3}(\mathrm{~g}) \rightleftharpoons \mathrm{NO}_{3}(\mathrm{aq})$ & $2.10 \times 10^{5}$ & 29.19 & 0 \\
\hline E5 & $\mathrm{OH}(\mathrm{g}) \rightleftharpoons \mathrm{OH}(\mathrm{aq})$ & $2.50 \times 10^{1}$ & 17.12 & 0 \\
\hline E6 & $\mathrm{HNO}_{3}(\mathrm{~g}) \rightleftharpoons \mathrm{HNO}_{3}(\mathrm{aq})$ & $2.10 \times 10^{5}$ & 0 & 0 \\
\hline E7 & $\mathrm{NH}_{3}(\mathrm{~g}) \rightleftharpoons \mathrm{NH}_{3}(\mathrm{aq})$ & $5.76 \times 10^{1}$ & 13.79 & -5.39 \\
\hline E8 & $\mathrm{SO}_{2}(\mathrm{aq})+\mathrm{H}_{2} \mathrm{O} \rightleftharpoons \mathrm{H}^{+}+\mathrm{HSO}_{3}^{-}$ & $1.71 \times 10^{-2}$ & 7.04 & 0 \\
\hline E9 & $\mathrm{HSO}_{3}^{-} \rightleftharpoons \mathrm{H}^{+}+\mathrm{SO}_{3}^{2-}$ & $5.99 \times 10^{-8}$ & 3.74 & 0 \\
\hline E10 & $\mathrm{HCl}(\mathrm{g}) \rightleftharpoons \mathrm{H}^{+}+\mathrm{Cl}^{-}$ & $1.97 \times 10^{+6}$ & 30.19 & 19.91 \\
\hline E11 & $\mathrm{HF}(\mathrm{g}) \rightleftharpoons \mathrm{H}^{+}+\mathrm{F}^{-}$ & 3.94 & 25.04 & 16.34 \\
\hline E12 & $\mathrm{NH}_{3}(\mathrm{aq})+\mathrm{H}_{2} \mathrm{O} \rightleftharpoons \mathrm{NH}_{4}^{+}+\mathrm{OH}^{-}$ & $1.85 \times 10^{-5}$ & -1.5 & 0 \\
\hline E13 & $\mathrm{H}_{2} \mathrm{SO}_{4} \rightleftharpoons \mathrm{H}^{+}+\mathrm{HSO}_{4}^{-}$ & $1.00 \times 10^{+3}$ & 0 & 0 \\
\hline E14 & $\mathrm{HSO}_{4}^{-} \rightleftharpoons \mathrm{H}^{+}+\mathrm{SO}_{4}^{2-}$ & $1.02 \times 10^{-2}$ & 8.85 & 25.14 \\
\hline
\end{tabular}


Table A3. Ash dissolution reactions and rate parameters.

\begin{tabular}{llccc}
\hline Species & Reaction & $\log k$ & $n$ & Reference \\
\hline Fayalite & $\mathrm{Fe}_{2} \mathrm{SiO}_{4}+4 \mathrm{H}^{+} \rightarrow 2 \mathrm{Fe}^{2+}+2 \mathrm{H}_{2} \mathrm{O}+\mathrm{SiO}_{2}$ & -5.80 & 1.0 & 1,2 \\
Magnetite & $\mathrm{Fe}_{3} \mathrm{O}_{4}+8 \mathrm{H}^{+} \rightarrow 2 \mathrm{Fe}^{2+}+\mathrm{Fe}^{3+}+4 \mathrm{H}_{2} \mathrm{O}$ & -8.59 & 0.28 & 1,2 \\
Hematite & $\mathrm{Fe}_{2} \mathrm{O}_{3}+6 \mathrm{H}^{+} \rightarrow 2 \mathrm{Fe}^{3+}+3 \mathrm{H}_{2} \mathrm{O}$ & -9.39 & 0.42 & 1,2 \\
Albite & $\mathrm{NaAlSi}_{3} \mathrm{O}_{8}+4 \mathrm{H}^{+} \rightarrow \mathrm{Na}^{+}+\mathrm{Al}^{3+}+3 \mathrm{SiO}_{2}+2 \mathrm{H}_{2} \mathrm{O}$ & -10.10 & 0.46 & 1,2 \\
Enstatite & $\mathrm{Mg}_{2} \mathrm{Si}_{2} \mathrm{O}_{6}+4 \mathrm{H}^{+} \rightarrow \mathrm{Mg}^{2+}+2 \mathrm{SiO}_{2}+2 \mathrm{H}_{2} \mathrm{O}$ & -9.30 & 0.24 & 1,2 \\
Wollastonite & $\mathrm{CaSiO}_{3}+2 \mathrm{H}^{+} \rightarrow \mathrm{Ca}^{2+}+\mathrm{SiO}_{2}+\mathrm{H}_{2} \mathrm{O}$ & -7.80 & 0.2 & 1,2 \\
Forsterite & $\mathrm{Mg}_{2} \mathrm{SiO}_{4}+4 \mathrm{H}^{+} \rightarrow \mathrm{Mg}^{2+}+\mathrm{SiO}_{2}+2 \mathrm{H}_{2} \mathrm{O}$ & -7.00 & 0.49 & 1,2 \\
Diopside & $\mathrm{CaMgSi}_{2} \mathrm{O}_{6}+4 \mathrm{H}^{+} \rightarrow \mathrm{Ca}^{2+}+\mathrm{Mn}^{2+}+2 \mathrm{SiO}_{2}+2 \mathrm{H}_{2} \mathrm{O}$ & -10.50 & 0.19 & 1,2 \\
Glass & $\mathrm{SiAl}_{0.36} \mathrm{O}_{2}(\mathrm{OH})_{1.08}+1.08 \mathrm{H}^{+}$ & -8.30 & - & 3 \\
& $\rightarrow \mathrm{SiO}_{2}+0.36 \mathrm{Al}$ & & & \\
\hline
\end{tabular}

* (1) Palandri and Kharaka (2004), (2) Bandstra et al. (2007), (3) Oelkers and Gislason (2001). 
Acknowledgements. We thank the reviewers for their comments that helped us to improve the manuscript. We also thank R. Hellmann and S. R. Gislason for the discussions concerning minerals and glass dissolution. This work is supported through the Cluster of Excellence CliSAP (EXC177) and School of Integrated Climate System Sciences (SICSS), Universität Hamburg.

Edited by: M. Ammann

\section{References}

Achterberg, E. P., Moore, C. M., Henson, S. A., Steigenberger, S., Stohl, A., Eckhardt, S., Avendano, L. C., Cassidy, M., Hembury, D., Klar, J. K., Lucas, M. I., Macey, A. I., Marsay, C. M., and Ryan-Keogh, T. J.: Natural iron fertilization by the Eyjafjallajökull volcanic eruption, Geophys. Res. Lett., 40, 921-926, 2013.

Atkins, P. W.: Physical Chemistry, Oxford Univ. Press, New York, 1986.

Ayris, P. M. and Delmelle, P.: Volcanic and atmospheric controls on ash iron solubility: A review, Phys. Chem. Earth, Parts A/B/C, 45-46, 103-112, 2012.

Ayris, P. M., Lee, A. F., Wilson, K., Kueppers, U., Dingwell, D. B., and Delmelle, $\mathrm{P}$.: $\mathrm{SO}_{2}$ sequestration in large volcanic eruptions: High-temperature scavenging by tephra, Geochim. Cosmochim. Ac., 110, 58-69, 2013.

Ayris, P. M., Delmelle, P., Cimarelli, C., Maters, E. C., Suzuki, Y. J., and Dingwell, D. B.: HCl uptake by volcanic ash in the high temperature eruption plume: mechanistic insights, Geochim. Cosmochim. Ac., 144, 188-201, 2014.

Bagnato, E., Aiuppa, A., Bertagnini, A., Bonadonna, C., Cioni, R., Pistolesi, M., Pedone, M., and Hoskuldsson, A.: Scavenging of sulphur, halogens and trace metals by volcanic ash: The 2010 Eyjafjallajökull eruption, Geochim. Cosmochim. Ac., 103, 138160, 2013.

Bandstra, J. Z., Buss, H. L., Campen, R. K., Liermann, L. J., Moore, J., Hausrath, E. M., Navarre-Sitchler, A. K., Jang, J. H., and Brantley, S. L.: Kinetics of Water Rock Interactions, chap. Appendix: Compilation of Mineral Dissolution Rates, Springer,731-733, 2007.

Bayhurst, G. K., Wohletz, K. H., and Mason, A. S.: Volcanic ash and aviation safety: Proceedings of the First International Symposium on Volcanic Ash and Aviation Safety, chap. A method for characterizing volcanic ash, 16 pp., USGS, 1991.

Blesa, M. A., Morando, P. J., and Regazzoni, A. E.: Chemical Dissolution of Metal Oxides, CRC Press, 1994.

Blundy, J., Cashman, K., and Humphreys, M.: Magma heating by decompression-driven crystallization beneath andesite volcanoes, Nature, 443, 76-80, 2006.

Bobrowski, N., von Glasow, R., Aiuppa, A., Inguaggiato, S., Louban, I., Ibrahim, O. W., and Platt, U.: Reactive halogen chemistry in volcanic plumes, J. Geohys. Res. D, 112, D06311, doi:10.1029/2006JD007206, 2007.

Brown, R. J., Bonadonna, C., and Durant, A. J.: A review of volcanic ash aggregation, Phys. Chem. Earth, Parts A/B/C, 45, 6578, 2012.

Censi, P., Randazzo, L., Zuddas, P., Saiano, F., Aricò, P., and Andò, S.: Trace element behaviour in seawater during Etna's pyroclastic activity in 2001: Concurrent effects of nutrients and formation of alteration minerals, J. Volcanol. Geoth. Res., 193, 106-116, 2010.

Clement, F. C., Kulmala, M., and Vesala, T.: Theoretical consideration on sticking probabilities, J. Aerosol. Sci., 27, 869-882, 1996.

Delmelle, P., Villieras, F., and Pelletier, M.: Surface area, porosity and water adsorption properties of fine volcanic ash particles, Bull. Volcanol., 67, 160-169, 2005.

Delmelle, P., Lambert, M., Dufrene, Y., Gerin, P., and Óskarsson, N.: Gas/aerosol/ash interaction in volcanic plumes: New insights from surface analyses of fine ash particles, Earth. Planet. Sci. Lett., 259, 159-170, 2007.

Desboeufs, K., Losno, R., and Colin, J.: Factors influencing aerosol solubility during cloud processes, Atmos. Environ., 35, 35293537, 2001.

Dingwell, D. B., Lavallee, Y., and Kueppers, U.: Volcanic ash: A primary agent in the Earth system, Phys. Chem. Earth, Parts A/B/C, 45-46, 2-4, 2012.

Duggen, S., Olgun, N., Croot, P., Hoffmann, L., Dietze, H., Delmelle, P., and Teschner, C.: The role of airborne volcanic ash for the surface ocean biogeochemical iron-cycle: a review, Biogeosciences, 7, 827-844, doi:10.5194/bg-7-827-2010, 2010.

Fuchs, N. A. and Sutugin, A. G.: Highly Dispersed Aerosols, Ann Arbor Science Publ., Ann Arbor, Michigan, 1970.

Gerlach, T. M.: Volcanic sources of tropospheric ozonedepleting trace gases, Geochem. Geophys. Geosys., 5, Q09007, doi:10.1029/2004GC000747, 2004.

Gislason, S. R., Hassenkam, T., Nedel, S., Bovet, N., Eiriksdottir, E. S., Alfredsson, H. A., Hem, C. P., Balogh, Z. I., Dideriksen, K., Oskarsson, N., Sigfusson, B., Larsen, G., and Stipp, S. L. S.: Characterization of Eyjafjallajökull volcanic ash particles and a protocol for rapid risk assessment, Proc. Natl. Aca. Sci., 108, 7303-7312, 2011.

Hamilton, J. P., Pantano, C. G., and Brantley, S. L.: Dissolution of albite glass and crystal, Geochim. Cosmochim. Acta, 64, 26032615, 2000.

Hamme, R. C., Webley, P. W., Crawford, W. R., Whitney, F. A., DeGrandpre, M. D., Emerson, S. R., Eriksen, C. C., Giesbrecht, K. E., Gower, J. F. R., Kavanaugh, M. T., Panea, M. A., Sabine, C. L., Batten, S. D., Coogan, L. A., Grundle, D. S., and Lockwood, D.: Volcanic ash fuels anomalous plankton bloom in subarctic northeast Pacific, Geophys. Res. Lett., 37, L19604, doi:10.1029/2010GL044629, 2010.

Harris, E., Sinha, B., van Pinxteren, D., Tilgner, A., Fomba, K. W., Schneider, J., Roth, A., Gnauk, T., Fahlbusch, B., Mertes, S., Lee, T., Collett, J., Foley, S., Borrmann, S., Hoppe, P., and Herrmann, H.: Enhanced role of transition metal ion catalysis during in-cloud oxidation of $\mathrm{SO}_{2}$, Science, 340, 727-730, 2013.

Heiken, G. and Wohletz, K.: Volcanic ash, University of California Press, London, 1992.

Hort, M. and Gardner, J.: Constraints on cooling and degassing of pumice during Plinian volcanic eruptions based on model calculations, J. Geophys. Res.-Solid Earth, 115, 25981-26001, 2000.

Horwell, C. J., Fenoglio, I., Ragnarsdottir, K. V., Sparks, R. S. J., and Fubini, B.: Surface reactivity of volcanic ash from the eruption of Soufrire Hills volcano, Montserrat, West Indies with implications for health hazards, Environ. Res., 93, 202-215, 2003. 
Hoshyaripour, G., Hort, M., and Langmann, B.: How does the hot core of a volcanic plume control the sulfur speciation in volcanic emission?, Geochem. Geophys. Geosys., 13, 100-115, 2012.

Hoshyaripour, G., Hort, M., Langmann, B., and Delmelle, P.: High temperature volcanic controls on ash iron solubility: new insights from high-temperature gas-ash interaction modeling, J. Volcanol. Geotherm. Res., 286, 67-77, 2014.

Höskuldsson, A., Óskarsson, N., Pedersen, R., Grönvold, K., Vogfjörò, K., and Ólafsdóttir, R.: The millennium eruption of Hekla in February 2000, Bull. Volcanol., 70, 169-182, 2007.

Jacobson, M. Z.: Fundamentals of Atmospheric Modeling, Cambridge University Press, 2005.

Jeong, D., Kim, K., and Choi, W.: Accelerated dissolution of iron oxides in ice, Atmos. Chem. Phys., 12, 11125-11133, doi:10.5194/acp-12-11125-2012, 2012.

Jeong, K. and Levy, E. K.: Theoretical prediction of sulfuric acid condensation rates in boiler flue gas, Int. J. Heat. Mass. Tran., 55, 8010-8019, 2012.

Jones, M. T. and Gislason, S. R.: Rapid releases of metal salts and nutrients following the deposition of volcanic ash into aqueous environments, Geochim. Cosmochim. Ac., 72, 3661-3680, 2008.

Journet, E., Desboeufs, K. V., Caquineau, S., and Colin, J.-L.: Mineralogy as a critical factor of dust iron solubility, Geophys. Res. Lett., 35, L07805, doi:10.1029/2007GL031589, 2008.

Langmann, B., Zakšek, K., Hort, M., and Duggen, S.: Volcanic ash as fertiliser for the surface ocean, Atmos. Chem. Phys., 10, 38913899, doi:10.5194/acp-10-3891-2010, 2010.

Larkin, K.: Canada sees shock salmon glut, Nature News, September 2010, 2010

Lindsley, D. H.: Oxide minerals: petrologic and magnetic significance, vol. 25, Mineralogical Society of America Reviews in Mineralogy, 1991.

Mastin, L. G.: A user-friendly one-dimensional model for wet volcanic plumes, Geochem. Geophys. Geosys., 8, Q03014, doi:10.1029/2006GC001455, 2007.

Meskhidze, N., Chameides, W. L., and Nenes, A.: Dust and pollution: A recipe for enhanced ocean fertilization?, J. Geohys. Res., 110, D03301, doi:10.1029/2004JD005082, 2005.

Mills, O. P. and Rose, W. I.: Shape and surface area measurements using scanning electron microscope stereo-pair images of volcanic ash particles, Geosphere, 6, 805-811, 2010.

Moune, S., Gauthier, P. J., Gislason, S. R., and Sigmarsson, O.: Trace element degassing and enrichment in the eruptive plume of the 2000 eruption of Hekla volcano, Iceland, Geochim. Cosmochim. Ac., 70, 461-479, 2006.

Moune, S., Sigmarsson, O., Thordarson, T., and Gauthier, P. J.: Recent volatile evolution in the magmatic system of Hekla volcano, Iceland, Earth. Planet. Sci. Lett., 255, 373-389, 2007.

Moune, S., Holtz, F., and Botcharnikov, R. B.: Sulphur solubility in andesitic to basaltic melts: implications for Hekla volcano, Contrib. Mineral. Petrol., 157, 691-707, 2009.

Nakagawa, M. and Ohba, T.: Minerals in volcanic ash 1: Primary minerals and volcanic glass, Global Environ. Res., 6, 41-50, 2003.

Naughton, J. J., Lewis, V. A., Hammond, D., and Nishimoto, D.: The chemistry of sublimates collected directly from lava fountains at Kilauea volcano, Hawaii, Geochim. Cosmochim. Ac., 38, 1670-1690, 1974.
Oelkers, E. H.: General kinetic description of multioxide silicate mineral and glass dissolution, Geochim. Cosmochim. Acta, 63, 3703-3719, 2001.

Oelkers, E. H. and Gislason, S. R.: The mechanism, rates and consequences of basaltic glass dissolution: I. An experimental study of the dissolution rates of basaltic glass as a function of aqueous $\mathrm{Al}, \mathrm{Si}$, and oxalic acid concentration at $25 \mathrm{C}$ and $\mathrm{pH}=3$ and 11 , Geochim. Cosmochim. Ac., 65, 3671-3681, 2001.

Olgun, H., Duggen, S., Langmann, B., Hort, M., Waythomas, C. F., Hoffmann, L. J., and Croot, P.: Geochemical evidence of oceanic iron fertilization by the Kasatochi volcanic eruption in 2008 and the potential impacts on Pacific sockeye salmon, Mar. Ecol. Prog. Ser., 488, 81-88, 2013 a.

Olgun, N., Duggen, S., Croot, P. L., Delmelle, P., Dietze, H., Schacht, U., Oskarsson, N., Siebe, C., Auer, A., and GarbeSchonberg, D.: Surface ocean iron fertilization: The role of airborne volcanic ash from subduction zone and hot spot volcanoes and related iron fluxes into the Pacific Ocean, Global. Biogeochem. Cy., 25, GB4001, doi:10.1029/2009GB003761, 2011.

Olgun, N., Duggen, S., Andronico, D., Kutterolf, S., Croot, P. L., Giammanco, S., Censi, P., and Randazzo, L.: Possible impacts of volcanic ash emissions of Mount Etna on the primary productivity in the oligotrophic Mediterranean Sea: Results from nutrientrelease experiments in seawater, Mar. Chem., 152, 32-42, 2013b.

Óskarsson, N.: The interaction between volcanic gases and tephra: Fluorine adhering to tephra of the 1970 Hekla eruption, J. Volcanol. Geotherm. Res., 8, 251-266, 1980.

Palandri, J. L. and Kharaka, Y. K.: A Compilation of Rate Parameters of Water-Mineral Interaction Kinetics for Application to Geochemical Modeling, USGS, 2004.

Parsons, T. R. and Whitney, F. A.: Did volcanic ash from Mt. Kasatoshi in 2008 contribute to a phenomenal increase in Fraser River sockeye salmon (Oncorhynchus nerka) in 2010?, Fish. Oceanogr., 21, 374-377, 2012.

Pirjola, L., Kulmala, M., Wilck, M., Bischoff, A., Stratmann, F., and Otto, E.: Formation of sulphuric acid aerosols and cloud condensation nuclei: an expression for significant nucleation and model comparison, J. Aerosol. Sci., 30, 1079-1094, 1999.

Robock, A.: Volcanic eruptions and climate, Rev. Geophys., 38, 191-219, 2000.

Rose, W. I.: Scavenging of volcanic aerosol by ash: Atmospheric and volcanologic implications, Geology, 5, 621-624, 1977.

Rose, W. I. and Durant, A. J.: Total grain size distribution of explosive volcanic eruptions., J. Volcanol. Geotherm. Res., 186, 32 39, 2009.

Sander, S. P., Abbatt, J., Barker, J. R., Burkholder, J. B., Friedl, R. R., Huie, D. M. G. R. E., Kolb, C. E., Kurylo, M. J., Moortgat, G., Orkin, V. L., and Wine, P. H.: Chemical kinetics and photochemical data for use in atmospheric studies, Evaluation No. 17, Jet Propulsion Laboratory, Pasadena, 2011.

Sarmiento, J. L.: Atmospheric $\mathrm{CO}_{2}$ stalled, Nature, 365, 697-698, 1993.

Schmincke, H. U.: Volcanism, Springer-Verlag, Berlin Heidelberg, 2004.

Schroth, A. W., Crusius, J., Sholkovitz, E. R., and Bostick, B. C.: Iron solubility driven by speciation in dust sources to the ocean, Nat. Geosci., 2, 337-340, 2009.

Schwertmann, U.: Solubility and dissolution of iron oxides, Plant and Soil, 130, 1-25, 1991. 
Seinfeld, J. H. and Pandis, S. N.: Atmospheric Chemistry and Physics: From Air Pollution to Climate Change, John Wiley and Sons, New York, 2006.

Shampine, L. F. and Reichelt, M. W.: The MATLAB ODE Suite, SIAM J. Sci. Comput., 18, 1-22, 1997.

Sidhu, P. S., Gilkes, R. J., Cornell, R. M., Posner, A. M., and Quirk, J. P.: Dissolution of iron oxides and oxyhydroxides in hydrochloric and perchloric acids, Clays Clay Miner., 29, 269-276, 1981.

Sparks, R. S. J., Bursik, M. I., Carey, S. N., Gilbert, J. S., Glaze, L. S., Siggurdsson, H., and Woods, A. W.: Volcanic Plumes, John Wiley and Sons, New York, 1997.

Stumm, W. and Morgan, J.: Aquatic chemistry: chemical equilibria and rates in natural waters, A Wiley-Interscience publication, 1996.

Symonds, R. B., Rose, W. I., Bluth, G. J. S., and Gerlach, T. M.: Volatiles in Magma, chap. Volcanic gas studies: methods, results and applications, pp. 1-66, Reviews in Mineralogy, vol. 30. American Mineralogical Society, 1994.

Tabazadeh, A. and Turco, R. P.: Stratospheric chlorine injection by volcanic eruptions: $\mathrm{HCl}$ scavenging and implications for ozone, Science, 260, 1082-1086, 1993.

Textor, C., Graf, H. F., Herzog, M., and Oberhuber, J. M.: Injection of gases into the stratosphere by explosive volcanic eruptions, J. Geophys. Res.-Atmos., 108, 4606, doi:10.1029/2002JD002987, 2003.

Textor, C., Graf, H., Longo, A., Neri, A., Ongaro, T. E., Papale, P., Timmreck, C., and Ernst, G. G. J.: Numerical simulation of explosive volcanic eruptions from the conduit flow to global atmospheric scales, An. Geophys., 48, 817-842, 2005.
Textor, C., Graf, H. F., Herzog, M., Oberhuber, J., Rose, W. I., and Ernst, G. G. J.: Volcanic particle aggregation in explosive eruption columns. Part II: Numerical experiments, J. Volcanol. Geotherm. Res., 150, 378-394, 2006a.

Textor, C., Graf, H. F., Herzog, M., Oberhuber, J. M., Rose, W. I., and Ernst, G. G. J.: Volcanic particle aggregation in explosive eruption columns. Part I: Parameterization of the microphysics of hydrometeors and ash, J. Volcanol. Geotherm. Res., 150, 359377, $2006 b$.

US Committee on Extension to the Standard Atmosphere: U.S. Standard Atmosphere, Natl. Oceanic and Atmos. Admin., Washington, DC, 1976.

Verhoff, F. H. and Banchero, J. T.: Predicting dew points of gases, Chem. Eng. Prog., 78, 71-72, 1974.

Wang, B., Michaelson, G., Ping, C., Plumlee, G., and Hageman, P.: Characterization of Pyroclastic Deposits and Pre-eruptive Soils following the 2008 Eruption of Kasatochi Island Volcano, Alaska, Arct., Antarc., Alp. Res., 42, 276-284, 2010.

Watson, A. J.: Volcanic Fe, $\mathrm{CO}_{2}$, ocean productivity and climate, Nature, 358, 587-588, 1997.

Wolff-Boenisch, D., Gislason, S. R., and Oelkers, E. H.: The effect of fluoride on the dissolution rates of natural glasses at $\mathrm{pH} 4$ and $25^{\circ} \mathrm{C}$, Geochim. Cosmochim. Ac., 68, 4571-4582, 2004. 